\title{
Arbitrismo y reforma monetaria en tiempos de Carlos II
}

\author{
Juan A. Sánchez Belén *
}

"Es la moneda en el cuerpo de la república lo que el aire en el cuerpo humano, que a un mismo tiempo vivifica o mortifica todas sus partes, pues a un mismo tiempo o conserva en igualdad o altera en desproporciones todo el comercio humano" ?.

\section{INTRODUCCIÓN}

El marasmo producido en el sistema monetario de Castilla por las alteraciones practicadas en la moneda de vellón por Felipe 11 l y luego por su hijo Felipe IV ${ }^{2}$ originó a la vez una inflación de los precios difícil de atajar y un incremento en la cotización de la plata respecto del vellón, lo que afectó por igual a la economía del pais y a la Real Hacienda. A la primera, porque el elevado coste de los productos castellanos hizo que no fuesen competitivos frente a los elaborados en el extranjero; a la se-

* Profesor Titular de Historia Moderna. UNED.

Muñoz SúAREz, Sebastián, Señora... las enfermedades de que adolece el reino proceden principalmente de tres causas: la falta de valor natural en las monedas de cobre y mezcla y la subida, por esta razón, en la de plata y oro; lo excesivo de los portes de la carestia de la cebada y, por ella, todos los géneros, y luego los tributos... BNM (Biblioteca Nacional de Madrid), VE (Varios Especiales), 210/13, fol. 1.

"Hamlton, E. J., "Inflación monetaria en Castilla (1598-1660)", El florecimiento del ca-

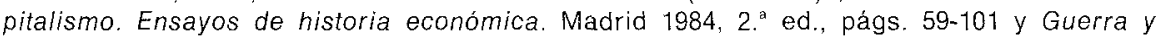
precios en España, 1650-1800. Madrid 1988, págs. 37-47. Dominguez Ortiz, A. Política y hacienda de Felipe IV. Madrid 1960, págs. 251-279. 
gunda, porque las provisiones de dinero para Flandes, Italia e incluso Aragón o Cataluña se tenían que realizar en plata, mientras que las recaudaciones de los contribuyentes se percibian en vellón, debiendo abonar la Corona a los asentistas que se encargaban de tales transferencias un premio por la operación de convertir la moneda de cobre en plata, lo cual reducía sensiblemente el rendimiento obtenido de los impuestos ${ }^{3}$.

Durante los quince primeros años del reinado de Carlos II los arbitristas plantearon al monarca y sus ministros la necesidad de reformar el sistema monetario vigente por los perjuicios que ocasionaba, buscando adecuar el valor nominal de las monedas al valor intrínseco, además de reajustar la paridad entre el oro, la plata y el cobre, homologando el peso y la ley de las piezas de metal noble a los establecidos en Europa, de suerte que se erradicara su extracción continuada del reino, se asegurara el comercio y se fomentaran las actividades productivas. Como expone un autor anónimo de la regencia, siempre que la moneda «no fuera de buena ley y no tuviera su valor intrínseco, estará sujeta a altas y bajas con grave daño del público, riesgo del príncipe y atrasamiento de su servicio" ${ }^{4}$. Nuestro propósito es abordar el estudio de tales proyectos y su impronta en las reformas monetarias llevadas a cabo en 1680 y 1686. Antes, sin embargo, es preciso definir el sistema en uso hacia 1665, pues de otro modo no se comprenderá el alcance de las ideas expuestas por los contemporáneos en sus memoriales ni lo acertado o errado de las mismas.

\section{LA MONEDA CASTELLANA EN 1665}

Al iniciarse la regencia de doña Mariana de Austria el numerario que circulaba en Castilla estaba integrado por: el escudo, de oro, con sus múltiplos (doblón, doblón de a cuatro y onza de oro con valor de ocho escudos); el real de plata con los suyos (real de a dos, real de a cuatro y real de a ocho); y piezas de dieciséis, ocho, cuatro y dos maravedíes. Las monedas de cuenta, por otro lado, eran: el ducado (equivalía a once rea-

\footnotetext{
Sobre este punto, además del libro ya citado de Domínguez Ortiz en la nota anterior, se puede consultar el estudio de BoYajan, J. C., Portuguese Bankers at the Court of Spain, 1626-1650. New Yersey 1983, págs. 71-102 y 154-180, y el de Sanz Ayá, C., Los banqueros de Carlos II. Valladolid 1989.

${ }_{4}^{4}$ Anónimo, Discurso sobre el Estado de la nación y remedios..., BNM. Mss 10.695, fol. $89 \mathrm{~V}$.
} 
les de plata o de vellón, según se especificara); el real de vellón (treinta y cuatro maravedies de vellón); el cuartillo (un cuarto de real de plata); el cuarto (cuatro maravedies); y el ochavo (dos maravedies).

El escudo debia tener una ley de veintidós quilates y se tallaban sesenta y ocho piezas por marco, es decir, sesenta y ocho piezas por doscientos treinta granos, to que daba un peso por moneda de 3,38 gramos. Sus múltiplos tenían igual ley y talla equivalente, o lo que es 10 mismo, se tallaban 8,5 onzas de oro por marco, con un peso de 27,05 gramos por pieza. El real de plata tenían una ley de once dineros y cuatro gramos 0 ley de doscientos sesenta y ocho granos - la pura tenía doce dineros o doscientos ochenta y ocho granos) y se tallaban sesenta y siete piezas por marco (34,3 gramos por pieza). La relación oro-plata, en cuanto a peso, era de 1/68 a 1/67 y el valor del escudo respecto de la plata era de catorce a uno. La valencia entre ambos metales era de quince a uno.

En cuanto a la moneda de vellón, la Pragmática de 29 de octubre de 1660 había establecido su consumo y la acuñación de piezas de cobre ligado con plata, con talla de veinticuatro reales el marco y veinte granos de plata, lo que daba cincuenta y una piezas por marco para las monedas con valor facial de dieciséis maravedies, ciento dos piezas por marco para las de ocho maravedies y así sucesivamente. La medida, sugerida por don Juan de Góngora a fin de obviar las posibles objeciones de las Cortes, que insistian en que no se labrase más moneda de cobre, supuso un beneficio sustancioso a la Real Hacienda, pues por cada millón de ducados labrados quedaban libres 565.000 ducados, una vez deducidos los gastos de obreaje y el importe de la plata (200.000 ducados) y del cobre (79.444 ducados) utilizados en la acuñación ${ }^{5}$. El alto contenido de plata de estas monedas, vulgarmente denominadas de "molino», facilitó su falsificación, introduciéndose en el reino un enorme volumen de piezas de solo cobre, con igual o inferior peso, lo que indujo al Consejo de Hacienda en 1663 a proponer al soberano fuese retirada de la circulación ${ }^{6}$. No se ejecutó así, pero el 14 de octubre de 1664 una nueva Pragmática depreció su poder liberatorio a la mitad (las piezas de dieciséis maravedies valdrian ocho y en la misma proporción las restantes piezas), aproximando asi su valor al intrínseco: 7,33 maravedies ${ }^{7}$. No obstante, la

Dominguez Ortiz, A., Op. cit., pág. 269. Nueva Recopilación, Auto XXVI, tít. XXI, lib. V.

- Garzon Pareja, M., La hacienda de Carlos II. Madrid 1980, pág. 400.

7 Nueva recopilación, Auto XXVIII, tít XXI, lib. V. El valor intrínseco de la moneda de molino fabricada en 1660, según los datos de Domínguez Ortiz, era el siguiente: 24 reales/ marco - 13 reales/marco de beneficio para la Real Hacienda $=11 \mathrm{reales} / \mathrm{marco}$. Como 
abundancia de moneda de cobre fabricada fuera de España y en la peninsula, junto con la extracción de la moneda de molino, originó una revalorización en el mercado de los reales de plata y por lo tanto, que éstos se cotizasen al alza con un premio del cincuenta por ciento a comienzos de 1665, modificando la relación teórica que hacia que el real de plata equivaliese a treinta y cuatro maravedies. De este modo, y teniendo en cuenta el citado premio, la equivalencia entre las distintas monedas en curso era la siguiente ${ }^{8}$.

\begin{tabular}{|c|c|c|c|c|}
\hline MONEDAS & ESCUDOS & $\begin{array}{l}\text { REALES } \\
\text { DE PLATA }\end{array}$ & $\begin{array}{l}\text { REALES } \\
\text { DE VELLOON }\end{array}$ & MARAVEDIES \\
\hline 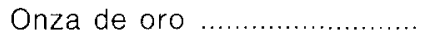 & 8 & 112 & 168 & 5.172 \\
\hline Doblón de a cuatro ............... & 4 & 56 & 84 & 2.856 \\
\hline 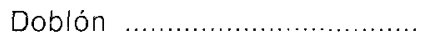 & 2 & 28 & 42 & 1.428 \\
\hline 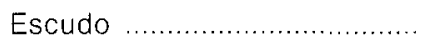 & 1 & 14 & 21 & 714 \\
\hline 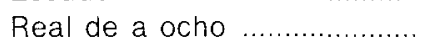 & - & 8 & 12 & 408 \\
\hline 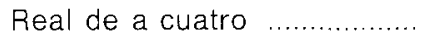 & - & 4 & 6 & 204 \\
\hline 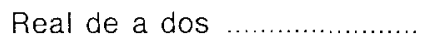 & - & 2 & 3 & 102 \\
\hline 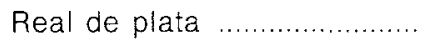 & - & 1 & 1,5 & 51 \\
\hline Medio real ............................. & - & 0,5 & 0,75 & 25,5 \\
\hline $\begin{array}{r}\text { Maravedi de plata (Moneda } \\
\text { de cuenta) }\end{array}$ & - & - & 一 & 1,5 \\
\hline $\begin{array}{r}\text { Carilla (pieza de } 16 \text { marave- } \\
\text { dies) }\end{array}$ & - & - & - & 8 \\
\hline Pieza de 8 maravedies ........ & - & - & - & 4 \\
\hline Pieza de 4 maravedies ........ & - & - & - & 2 \\
\hline Pieza de 2 maravedies ........ & - & 一 & - & 1 \\
\hline $\begin{array}{l}\text { Real de velion (moneda de } \\
\text { cuenta) }\end{array}$ & - & - & 1 & 34 \\
\hline Ducado (moneda de cuenta). & - & 11 & 11 & 374 \\
\hline
\end{tabular}

por cada marco se acuñaban 51 piezas, el valor de éstas era de

$$
11 \text { reales } \times 34 \text { maravedies }=\begin{gathered}
374 \text { maravedies } \\
51 \text { piezas }
\end{gathered}=71 \text { piezas }=73 \mathrm{mrs} / \text { pieza }
$$

Este valor era bastante inferior al facial, de 16 maravedies. Con la depreciación de 1.664 cada pieza de 16 maravedies queda reducida a 8 maravedies, lo que aproximaba el valor facial al intrinseco.

${ }^{8}$ Para todo este apartado es imprescindible la lectura del articulo de Collantes PérezArda, E. y Merino Navarro, J. P., "Alteraciones al sistema monetario en Castilla durante el reinado de Carlos II", Cuadernos de Investigación Histórica, 1, 1977, págs. 73-98. Un estudio comparado de las monedas hispánicas del siglo XVII en VILAR, P., Oro y moneda en la historia, 1450-1920. Barcelona 1972, 2. ${ }^{a}$ ed., págs. 329-339. 
Aunque la legislación venia admitiendo que el premio de la plata respecto del vellón fuese del cincuenta por ciento, a finales de 1665 éste se habia elevado ya al ciento dieciocho por ciento, lo que suponía que un real de plata pasó a cotizarse de cincuenta y un maravedies a setenta y cuatro maravedies. Esta depreciación se fue acentuando en años posteriores al no poderse atajar la entrada de moneda falsa de cobre, sin liga de plata, con igual peso que la moneda de molino (4,51 granos), y de otra más feble de igual tamaño. En 1669, según fray Juan de Jesús, la diferencia entre la plata y el vellón se habia situado en un ciento cincuenta por ciento, mientras que la relación oro-vellón era de un ciento ochenta y siete por ciento ${ }^{9}$. En 1677, el británido Jorge Wallis cifraba el premio de la plata en un doscientos doce por ciento y el del oro en un doscientos cincuenta y siete por ciento ${ }^{10}$. Ignoramos si su estimación pecaba por defecto o se ajustaba a la realidad. En cualquier caso, en visperas de la reforma monetaria de 1680 sabemos que el premio de la plata habia ascendido al doscientos setenta y cinco por ciento ${ }^{11}$. Ante esta situación, con una moneda de molino depreciada en relación con la plata y el oro, ¿qué medidas se podían adoptar? Los proyectos arbitristas de estos años vienen a plantear soluciones posibles para que los metales nobles permanezcan en el reino en circulación, así como para que la moneda de molino tenga justa proporcionalidad con las anteriores, reduciendo el premio o estabilizándole en una cantidad que no supere el cincuenta por ciento.

PROYECTOS REFORMISTAS ANTERIORES A LA PRAGMÁTICA DE FEBRERO DE 1680

Saavedra Fajardo, imbuido del pensamiento de su época, muy conservador en asuntos monetarios, advierte en su libro /dea de un príncipe político-cristiano sobre los peligros que entraña manipular la moneda, alterando su valor facial respecto al intrínseco. No obstante, cuando dicha relación se halla modificado por causas ajenas a la voluntad del sobe-

\footnotetext{
\& Jesus, Fray Juan de, El conocimiento del hombre es limitado y asi si camina por sí solo, sin el auxilio de Dios y sin caridad, nada obrará con acierto. Para remediar a Castilla se deben adoptar los pasos siguientes... BNM, Mss 19.700 2, fol. 1.

${ }^{10}$ AGS (Archivo General de Simancas), CJH (Consejo y Juntas de Hacienda), leg. 1.369. Memorial del Maestre del Campo Don Jorge Wallis, gentilhombre de la Cámara privada del rey de la Gran Bretaña, año 1677.

1 Hamilton, E. J., Guerra y precios..., pág. 48
} 
rano, entonces es licito buscar el equilibrio entre ambos valores, como también lo es pretender aproximar la paridad oro-plata a la que existe en otros estados de Europa. ${ }^{12}$. Menos pacatos que nuestro diplomático, los arbitristas de las décadas de 1660 y 1670 no dudan en abordar esta cuestión, quizá porque el daño ya estaba hecho y pretender erradicarlo era un deber inexcusable.

Uno de los primeros autores que realiza un diagnóstico perfecto de los perjuicios del sistema monetario vigente en su tiempo es Francisco Centani, buen conocedor, por otra parte, de los mecanismos de la hacienda castellana y un destacado hombre de negocios ${ }^{13}$. En un memorial presentado en 1665 comienza subrayando los problemas financieros que acarrea a la Corona el uso de la moneda de vellón gruesa - habia sido suprimida por la pragmática de 1660-, ya que todos los años produce más de 200.000 ducados de pérdidas al erario dado que los asentistas exigen en sus contratos mayores bonificaciones en concepto de "gasto de conducción» por el transporte y manejo de esta moneda, muy pesada, aparte de que como medio de pago resulta instisfactoria ${ }^{14}$. Señala asimismo en su escrito la poca estima que se da en el país a la moneda de molino, mucho mejor que la anterior y que la de calderilla, aún cuando esta última goza del favor de los súbditos por parecerles que es muy poca la que se ha introducido falsificada. Tras esto pasa a estudiar las monedas de plata y oro. A su juicio, la primera tiene un poder liberatorio inferior al que se le da en Europa (un veinticinco por ciento menos) y lo mismo sucede con la segunda (un veinticuatro por ciento infravalorada). Por estas consideraciones cree oportuna la reforma del sistema monetario de tal modo que «en mucho tiempo no haya necesidad de volver a hablar en variación, pues la experiencia enseña los grandes daños que de esto se originan" "'. ¿Qué se debe obrar en este sentido? Ante todo, la moneda de vellón gruesa, "que es la que en si tiene más valor», se ha de prohibir en aquellas transacciones que excedan los cien ducados, salvo en Madrid, para asi reducir el coste de la conducción. La de calderilla

\footnotetext{
12 SaAvedra Fajardo, D., Idea de un principe político-cristiano representada en cien empresas... Madrid 1947, Empresa LXIX, págs. 192b-193b.

13 Por el momento el único trabajo que ofrece más información sobre la vida de Francisco Centani es el de Sanz AyAn, C., "Francisco Centani, un hombre de negocios del siglo XVII", Moneda Crédito, 193, 1985, págs. 35-45. Acerca de su pensamiento económico y fiscal, Sureda Carrión, J. L., "Las doctrinas fiscales de Jacinto Alcázar y Francisco Centani», Anales de Economia, 24, 1945, págs. 379-401 y La hacienda castellana y los economistas del siglo XVII. Madrid 1949. Un resumen de sus ideas en Grice-Hutchinson, M., El pensamiento económico en España (1177-1740). Barcelona 1982, págs. 201-203.

${ }^{14}$ Hamilton, E. J., Inflación monetaria en Castilla..., págs. 97.

15 BNN, Mss 6.579, fols 8-8v.
} 
se podrá mantener en su valor y la de molino -esto es importante de cara al futuro- convendrá bajar a la mitad su valor facial, de suerte que "un marco que hoy vale doce reales quede en seis», asegurándose con este procedimiento la circulación de moneda de buena ley y no la falsa que se ha introducido por los beneficios que los falsificadores obtenian. En cuanto a las monedas de oro y plata, sustenta que a los reales de a ocho se les otorgue un valor de diez reales, aplicándose la misma proporción a las demás piezas de a cuatro, de a dos y sencillos; el doblón, por otro lado, se deberá cotizar a cuarenta reales. Estamos, pues, en presencia de una deflación de la moneda de molino y en una apreciación facial de las de oro y plata, acercando sus valores nominales a los que estaban en vigor en el continente europeo, con la que se evitaría su saca del reino, beneficiando de paso al Estado que efectuaba sus pagos internacionales en plata. Para evitar que los extranjeros y los nacionales recorten y limen las piezas, reduciendo su peso en un catorce o en un quince por ciento, 10 más acertado - concluye Francisco Centani-- es que en adelante los doblones de a ocho, de a cuatro y de a dos, asi como los reales, se labren con forma redonda, según se hace en la ceca de Segovia, y en el canto se les ponga unas letras que indiquen el año de su labor y la casa; los doblones y los reales de a cuatro y de a dos se acuñarán también con forma redonda, sin letras en el canto ${ }^{16}$.

En 1667 el licenciado don José Calero Gallego arremete contra la moneda de vellón calificándola como la enemiga mayor que tiene el reino y la que ha destruido a la Real Hacienda, motivo por el cual sugiere su consumo y sustitución por otra moneda de plata. Para obviar el argumento de que es imposible emprender dicha acuñación por la falta que hay del citado metal propone confiscar todo el que venga en la Flota y Galeones, especialmente el destinado a los mercaderes extranjeros, a quienes se entregará luego la mitad de lo que montare su valor en moneda de vellón y el resto en moneda de plata y oro, pudiendo la Corona vender el vellón sobrante en Holanda al precio fijado por el mercado para el cobre ${ }^{17}$.

Frente a este arbitrio, a todas luces utópico y poco fundado, nos encontramos dos años después, en 1669, con el propuesto por fray Juan de Jesús. Para este autor, en contra del sentir de Francisco Centani, la moneda de molino es la que se debe extinguir por «haber tiranizado y en-

\footnotetext{
${ }^{16}$ Ibidem, fol $8 \mathrm{~V}$.

17 Calero Gallego, J., Advertencias útiles para la buena y perfecta administración de las rentas y alivio de los vasallos..., 16 de julio de 1667, B L (British Library), Eggenton (Egg), 2.084 , fol $319-320$.
} 
carecido todas las cosas y puesto un real de a ocho en veinte reales y un doblón en ochenta reales". Simultáneamente propicia consumir la calderilla por no ajustarse entre sí los valores facial e intrinseco, muy superior el primero al segundo, con lo cual los extranjeros "ganan mucho en falsearla, y lo hacen con evidencia, y se conoce la falsa", o, si se prefiere, bajar su poder liberatorio a la mitad. Al mismo tiempo, es partidario de que sólo se acuñen piezas de plata, en concreto reales de a dos, sencillos y medios reales para facilitar las transacciones comerciales en el interior del país ${ }^{18}$. En esta línea se manifiesta Sebastián Muñoz Suárez en un memorial presentado también en 1669. Como fray Juan de Jesús, propugna que se consuma la moneda de molino y que la de calderilla se acomode al valor de su acuñación. En lo que difiere con el anterior es en la moneda de vellón grueso; ésta se debe suprimir asimismo de la circulación o, todo lo más, labrarla de nuevo «con igualdad en las piezas», ya que al presente «lo mismo valen ocho reales que pesan una libra que ocho reales que pesan dos libras». En cuanto a las monedas nobles sostiene, con Francisco Centani, en que se sobretasen, cotizándose el real de a ocho en doce reales y el doblón en cuarenta reales. Para el comercio menudo sugiere que se acuñen piezas de cobre puro, sin mezcla de plata. Con esta reforma opina que las monedas volverán a estimarse y, en consecuencia, «no se reservarán las otras (las de plata), que es lo que causa parecer que hay falta de ellas», aparte de que descenderá el premio del oro y de la plata y con ello el de todas las mercancias, puesto que los mercaderes, "considerando la dificultad de subsistencia de las monedas que reciben, se cautelan con el exceso en lo que venden", de tal modo que se hallan sin hacienda la mayor parte de los vasallos y sólo se benefician quienes perciben «sueldos en plata» ${ }^{19}$. No se limita Muñoz Suárez a ofrecer un sistema monetario alternativo a! que existe, sino que además esboza el procedimiento que la Corona debe adoptar para realizar la reforma aconsejada. En primer lugar, se decretará el consumo de la moneda de molino en el plazo de cuatro meses, pero mientras se ejecuta podrá utilizarse por la mitad de su valor nominal. El coste que acarreará esta medida correrá por cuenta de la Real Hacienda y de los súbditos proporcionalmente. Por eso se autorizará a los pueblos que abonen sus débitos anteriores a 1667 en moneda de molino por el valor que tiene y se ordenará a todos los vasallos que la registren y la envien a las Casas de Moneda donde se les dará a cambio piezas de nuevo cuño. Aparte de esto, el monarca destinará lo recaudado

18 Jesús, Fray de, Op. cit., fols. 1-1v.

19 Muñoz SuÁrez, S., Op. cit., fols. 1-3v. 
en concepto de condenaciones y penas de Cámara así como la bonificación que se otorgó a Madrid en sus sisas para el desempeño y los caudales agregados al erario tras las resoluciones acordadas por la "Junta de Alivios" en 1669 sobre reducción del gasto público ${ }^{20}$. Los súbditos privilegiados tampoco quedan marginados de la financiación del proyecto: quienes se benefician de mercedes y los caballeros de las Ordenes Militares «que no han militado» deberán contribuir con una suma determinada, lo mismo que los propietarios de mulas, caballos y coches, los funcionarios que gozan sueldos en moneda de plata, los juristas, los asentistas por sus inmoderados contratos, los mercaderes extranjeros por las ganacias que obtienen de vender sus mercancías y los eclesiásticos por vía de donativos supuesto que se verán tan favorecidos como los seglares. Finalmente, si estos medios no bastasen, se podrá recurrir al expediente de confiscar una porción de los caudales procedentes de América, dando satisfacción a sus dueños en la moneda que se acuñe ${ }^{21}$

Francisco Centani, fray Juan de Jesús y Sebastián Muñoz Suárez, entre otros arbitristas, no vieron prosperar sus proyectos a pesar de la certeza del diagnóstico y lo fundado de sus consejos, quizás porque estaba muy reciente en el ánimo de todos la devaluación de la moneda de molino de 1664 y sus efectos negativos en el comportamiento del premio de la plata y en la dinámica de los precios, cada vez con tendencia más alcista. Aparentemente, la Corona desaprovechó una ocasión única en 1669 al no asumir la reforma monataria que se preconizaba desde distintos sectores de la sociedad, pero ni entonces ni en los años inmediatamente posteriores estaba en situación de afrontarla, aparte del natural temor a sus consecuencias: por un lado, el empeño de las rentas no permitía desviar dinero para consumir la moneda de molino ni para acuñar otra que la sustituyera, aún cuando las remesas de plata y de oro procedentes de América trajeron para el rey en 1670 unos 2.389 .974 pesos como poco ${ }^{22}$; por otra parte, la estabilidad política de la Monarquía pendía de un hilo, con la amenaza siempre latente de un nuevo intento de don Juan José de Austria por hacerse con el poder; en tercer lugar, la economía del reino mostraba todavia sintomas inequivocos de desgaste que, sin duda, se agravarían de alterarse el sistema monetario, provocando el desorden económico y financiero; finalmente, cabía la posibilidad de que al amparo de tales circunstancias Luis XIV suscitara un enfrentamiento militar con

\footnotetext{
* Para las propuestas de la Junta de Alivios, SÁnChez BelÉn, J. A., "La Junta de Alivios de 1669 y las primeras reformas de la Regencia", Espacio, Tiempo y Forma, 4, 1989, págs. 639-668.

21 Muñoz SuÁrez, S., Op. cit., fois. 4-4v.

22 Kamen, H., La España de Carlos II. Madrid 1981, pág. 213.
} 
España en los Paises Bajos, en Italia o en la zona pirenaica sin que se pudiera oponer resistencia efectiva por la falta de numerario, perdiendo plazas importantes o provincias incluso, pues tampoco contábamos con aliados capaces de auxiliarnos en esa coyuntura ${ }^{23}$.

El recelo de los ministros a modificar el sistema monetario contrasta con la decidida actitud de los arbitristas, que no cesan de promover la reforma. En 1670, por ejemplo, Francisco Navarrete y Velasco, corregidor de la villa de Quesada y su partido, la plantea a su vez porque así se facilitaria «la quietud y conservación universal», dada «la alteración de los precios y falta de comercio" "24. Un año después, Francisco Centani insiste en que las monedas se igualen «en tal proporción que, quedando en razonable crédito, bajen los precios de todos los géneros y reducción de la platan, pues de otro modo no se podrán acometer reformas fiscales que potencien el resurgir económico de los pueblos ${ }^{25}$. Por las mismas fechas, Pedro Diaz Márquez, citando a fray Héctor Pinto, Sancho de Moncada y Alonso de Carranza, propone que las monedas de oro y de plata tengan respecto del vellón «valores fieles, iguales, corrientes y circulares ${ }^{26}$. En 1675, Francisco Centani vuelve a pronunciarse sobre este asunto, si bien ahora, y al contrario de lo que habia expuesto en 1671 , supedita cualquier intento de reorganizar el sistema monetario a una previa reforma en la administración y cobranza de las rentas reales, aunque no omite señalar que el descrédito de la moneda «es la causa del au-

El libro anteriormente citado de H. Kamen nos ofrece una buena panorámica de conjunto del reinado de Carlos II. Sobre la situación de la Hacienda real se puede consultar el trabajo de Garzón Pareja, M., La hacienda de Carlos II. Madrid 1981 y "Sobre la hacienda del reinado de Carlos 11 , Miscelánea de Estudios dedicados al profesor Antonio Marin Ocete. Granada 1974, págs. 327-347. De don Juan José de Austria se ha ocupado recientemente CASTILla SOTO, Josefina, en varios articulos publicados en la revista Espacio, Tiempo y Forma (numeros 1 y 3 , de la serie IV) y sobre todo en su libro Don Juan José de Austria (hijo bastardo de Felipe (V): Su labor politica y militar. Madrid 1992.

${ }^{24} \mathrm{AHN}$ (Archivo Histórico Nacional), Conss (Consejos suprimidos), leg. 7.180, exp 163, Discurso 3.

25 Centan, F., Tierras: medios universales propuestos desde el año de seiscientos y sesenta y cinco hasta el de seiscientos y setenta y uno para que con planta, números, pesos y medidas tenga la Real Hacienda dotación fija para asistir a la Causa Pública, remedio y alivio general para los pobres, cortando fraudes de que han hecho patrimonio los que lo deminan. Madrid, 16 de junio de 1671, BNM, VE, 69/54, fol. 290.

25 BNM, VE, 1/3, fol. 3v. Hay varios ejemplares en dicha sección de este memorial. Para las ideas monetarias de Alonso de Carranza, muy relacionadas con las sustentadas por Tomás de Cardona, ver su obra Apuntamiento de las monedas... Madrid 1629. Una sintesis excelente de este problema, que no es otro que la subida del valor facial de la plata, formulado a finales del reinado de Felipe $\| 1 /$ y comienzos del de Felipe IV, es la de VILAR BERROGAN, J., "Una pauta del pensamiento monetarista castellano: La "Proposición" Cardona (1618-1628)". Dinero y Crédito (siglos xvl al xix). Actas del Primer Coloquio Internacional de Historia Económica, edición de Alfonso Otazu. Madrid 1978, págs. 448-457. 
mento de los precios" ${ }^{27}$. Idéntico interés suscita esta materia entre los extranjeros. El súbdito británico y maestre de campo, don Jorge Wallis, expone en un memorial remitido al Consejo de Hacienda para su estudio por Real Decreto de 16 de julio de 1677, que las dificultades financieras de la Monarquía radican fundamentalmente en el desorden monetario, achacable tan solo al Estado por permitir que los particulares hayan aumentado a su capricho el premio de la plata, cotizándose cada real de a ocho a veinticinco reales y el doblón de a dos a cien reales, «con el pretexto de la mucha moneda falsa de vellón que se entró sin ser de las Reales Casas, fabricada fuera y dentro de Españas, lo cual ha originado, de un lado, el endeudamiento de la Corona al tener que realizar sus provisiones para Flandes e Italia con un sobreprecio, siendo que los impuestos se recaudan en vellón, y de otro, lo que es más grave, la carestía de todos los artículos, visible en el comercio y en particular en las ventas de casas y tierras, donde únicamente se acepta plata o vellón con el premio que corresponde. Para atajar este daño, don Jorque Wallis aconseja restablecer «moneda de vellón intrínseca pura y que la plata valga a doce reales el real de a ocho y el doblón de a dos escudos a cuarenta y ocho reales». En definitiva, lo que preconiza es que se crezca el valor nominal de las monedas de oro y de plata, como lo habian propuesto Francisco Centani y Sebastián Muñoz Suárez ${ }^{28}$.

El pensamiento de este súbdito británico coincide en lo esencial con las ideas del capitán don Antonio Somoza y Quiroga. En 1677, al igual que los arbitristas precedentes, relaciona la penuria del Estado y el encarecimiento de las manufacturas y de los artículos de consumo básicos con la existencia de un considerable volumen de numerario de vellón en el mercado, lo que a su parecer produce siempre «alteración en la plata, asi por los recelos del comercio como por la propia estimación y más seguro trato que percibe este apreciado metal», sin olvidar que el superior valor facial de dichas monedas de cobre, incluida la de molino, in-

\footnotetext{
2/ BL, Egg, 2.084, fol 349. Las razones apuntadas para posponer la reforma monetaria carecen de fundamento: "Al presente no conviene tratar del remedio pues si se hiciese no se podrá poner en ejecución lo que aqui se propone, y en particular el cobrar más de cuatro millones que se deben de atrasos a la Real Hacienda, incluyendo este año de 1675, ni tampoco se podrá dar satisfacción a los acreedores, y faltando esto no será posible ajustar las provisiones tan precisas que son menester, por estar en tiempo tan adelante y mostrar la experiencia que siempre que se hace variación en moneda queda turbado el comercio por más de seis meses".

${ }^{28}$ AGS, $C J H$, leg. 1.369. El memorial concluye brindándose el autor a fabricar cinco millones de escudos en moneda de cobre o de plata. Ver también Mauro, Federic, «Moneda y finanzas de España vistas desde Londres (1670-1740)", Dinero y crédito..., págs. 173-186.
} 
centiva su falsificación ${ }^{29}$. La alternativa que presenta al sistema monetario en vigor es muy sencilla: refundir todo el numerario de plata que circula y acuñar "con la propia legitimación, peso y ley [...] reales de a ocho, de a cuatro y de a dos (segovianos), dándoles dos reales de más valor a cada real de a ocho, y a su respecto al de cuatro y de a dos, cuyo precio, por Real Pragmática, puede quedar estable para moneda provincial, con cuyo caudal puede el rey [...] pagar y recoger toda la moneda de molino que hoy corre de vellón" ${ }^{30}$. Lo mismo deberá hacerse con el oro, en conformidad "con el seis, siete y ocho por ciento que las Naciones dan de menos precio y valor que a la plata». En cuanto a la calderilla y vellón grueso, es de parecer que se conserve a fin de facilitar el comercio menudo, pudiéndose incluso acuñar si hubiese escasez con tal de que su poder liberatorio se ajuste a su valor intrínseco, "computándose dicha moneda de vellón [...] que se venga a hacer, cada real de a ocho por dieciséis, dieciocho y veinte reales de vellón» ${ }^{31}$. A lo que se opone tajantemente es a mantener en circulación la moneda de molino, aunque algunos sostengan que en tanto llegan los Galeones y Flota no conviene hacer mudanza y retirarla tras haberse labrado nuevas piezas de plata con el metal traido de América. También se resiste a que dicha moneda sea reemplazada por otra de vellón, ni siquiera teniendo «su valor natural», y, por supuesto, a que se acuñe más cantidad o se rebaje su valor facial por debajo del intrínseco, dado que esto supondría "arruinar los caudales de los vasallos y dar lugar para que las naciones la saquen, como hallen un solo maravedi de interés en cada moneda de cuatro" ${ }^{32}$. Por último, para atraer a las arcas reales la plata atesorada por los particulares y poderla labrar, recomienda que se les de la mitad, el tercio o la cuarta parte de beneficio en la nueva moneda que se acuñe, aplicando, en caso contrario, severas sanciones a quienes no la registren y entreguen, promulgándose que «no pueda correr, valer ni comerciar» transcurrido un plazo prudente de tiempo estipulado con anterioridad. Esta medida se deberá hacer extensiva a la plata que venga de Indias, la cual, además, podrá ser adquirida por la Corona a sus propietarios abonándoles «seis u ocho reales más en cada marco de lo que al presente corre, que es la cantidad en que los excusados mercaderes de plata la venden a las Naciones" ${ }^{33}$.

\footnotetext{
Somoza y Quiroga, A., Discurso del capitán... tocante a la estabilidad medios y dificultades que se consideran en la moneda de esta Corona de Castilla, dedicado a S. A. Srma. el Sr. Don Juan. Madrid, octubre de 1677, BNM, VE, 17/25, fols. 1-2.

30 ibidem, fols. 7-8.

31 ibidem, fol. 8 y fols. $13-14$.

s? Ibidem, fols. 2-5.

33 Ibidem, fols. 9-11.
} 
La paulatina subida del premio de la plata entre 1665 y 1679 y la evolución paralela en dicho período de la tasa de crecimiento anual de los precios, que se cifra en Castilla la Vieja en un 6,2 por ciento -en los cereales la tasa se sitúa en un 8,9 por 100-, muy superior a la tasa de crecimiento anual de los salarios, que gira en torno al 0,9 por 100 entre 1672 y $1679{ }^{34}$, con sus repercusiones negativas en la capacidad adquisitiva de los trabajadores y rentistas, fue una de las preocupaciones máximas de don Juan José de Austria desde su ascenso al poder en 1677. Sus esfuerzos por mantener ambas variables en sus límites fracasaron, sin embargo, por coincidir a un tiempo la guerra contra Francia, las malas cosechas y la última gran epidemia del siglo xvII. Estos tres factores propiciaron el aumento rápido de los precios de los artículos de consumo básicos, cuya tendencia alcista se venia apreciando desde al menos 1674 , lo que originó una serie de pasquines denunciando la política económica del valido ${ }^{35}$. Asimismo, la necesidad de procurar numerario para las tropas de los Países Bajos, Italia y Cataluña encareció considerablemente la plata, lo que explica el descenso de las provisiones en esta moneda y en vellón entre los años 1674-1678, fecha de la firma de la Paz de Nimega ${ }^{36}$. Para paliar la escasez de moneda de plata en circulación y dar ejemplo, don Juan José de Austria dispuso el 8 de abril de 1678 entregar en las cecas toda la plata de su casa, a excepción de la del oratorio. con la intención de acuñarla, usando en adelante vajillas de peltre y de vi-

\footnotetext{
3 HaMilton, E. J., Guerra y precios en España... págs. 156-158. La tasa de crecimiento anual de los precios la hemos elaborado a partir de los datos de este autor que expone en las páginas 273-284. La tasa de crecimiento de los salarios ha sido confeccionada tomando como muestra los salarios de un maestro albañil y un maestro carpintero de la ciudad de Sevilla, los cuales oscilan entre los catorce reales al dia de 1672 y los dieciséis reales al dia de 1679. Adrián GuTiérRez Alonso, por su parte, ha reconstruido los precios de los cereales, pan, carne y vino que se consume en la ciudad de Valladolid utilizando diversas fuentes, algunas ya consultadas por Hamilton. Según sus cálculos, entre 1675 y 1680 los precios alcanzan. en términos nominales, su máximo nivel, tanto en los cereales como en la carne y el vino. Por lo que se réiere a los salarios, éstos evolucionaron muy por debajo de los precios, ya se trate de salarios de la construcción o de salarios agricolas, de suerte que la capacidad adquisitiva de los trabajadores disminuyó sensiblemente. Ver Estudio sobre la decadencia de Castilla. La ciudad de Valladolid en el siglo xvit. Valladolid 1989, págs. $167-169,178-182$ y $184-187$.

${ }^{35}$ BNM, MSs 2.289, fols. 90-92; MSs 18.211, fols. 57-62 y 162-162v; Mss 18.216, fols. 21. 23v. Una sintesis de los panfletos satiricos contra el gobierno y la persona de don Juan José de Austria en Sátiras políticas de la España Moderna, Introducción y selección de Teófanes Egido. Madrid 1973, págs 184-197.

36 Sanz Ayán, C., Los banqueros de Carlos II, págs. 226-229.
} 
driado de Talavera y candelabros de azófar ${ }^{37}$. De nada sirvió su gesto, como tampoco abarató el precio de los cereales la compra de 400.000 fanegas de trigo para suplir la falta que habia a causa de las malas cosechas, tasar el pan (se prohibió vender las dos libras a más de veintiocho maravedies) o expedir una Pragmática dirigida a los corregidores y alcaldes mayores encomendándoles registrar los granos a!macenados en sus respectivas demarcaciones, tanto los pertenecientes a seglares como a eclesiásticos, con el propósito de evitar que fueran acaparados y vendidos a excesivos precios por su escasez ${ }^{38}$. En esta coyuntura, memoriales cual el presentado por el capitán Somoza y Quiroga debieron de influir en el valido y convencerle de lo urgente que iba resultando ya la reforma del sistema monetario aún a costa de sacrificios inmediatos para la población. Con todo, hasta el mes de marzo de 1679 no se adoptaron los mecanismos adecuados a dicho efecto. Seguramente la noticia de que la Flota y los Galeones traian remesas de plata importantes -en conjunto parece ser que transportaron 2.189 .450 pesos para el soberano y 20.323.173 pesos para particulares, si bien los datos consulares elevan esta última cifra a 21.583.202 pesos ${ }^{39}$ - animaron a don Juan José de Austria a no postergar por más tiempo la solución al caos monetario de Castilla, instituyendo una Junta especial encargada de abordar esta cuestión y arbitrar las medidas convenientes.

La "Junta de Moneda", como asi fue denominada, estaba integrada por el gobernador del Consejo de Hacienda, el duque de Medinaceli, a la sazón presidente del Consejo de Indias, don Antonio Monsalve, del Consejo de Castilla, fray Francisco de Reluz, confesor de Carlos II, y don Andrés de Villarán, del Consejo de Hacienda. Entre los meses de marzo y julio de 1679 celebra diferentes reuniones con ministros y financieros pulsando sus opiniones, a la vez que analiza los varios memoriales que se le presentan sobre la materia. Uno de ellos, con toda probabilidad, es el Discurso de Somoza y Quiroga que ya hemos comentado, pues este autor envía otros escritos a lo largo de dichos meses aclarando distintas dudas que su proyecto ha suscitado a los miembros de la Junta, insistiendo en que los reales de a ocho se tasen a diez reales y a su tenor las demás monedas de plata, según se cotizan en Europa, y que al oro se le de «un doce por ciento de menos valor que a la parte de quilates de plata, de manera que un doblón senciilo valga treinta y seis reales de moneda de plata doble y cuarenta de la provincial y menuda». Reitera asimismo que

Castilla Soto. J. Don Juan josé de Austria... pág. 300

34 AHN Conss, libro 1.474. Pragmática de 17 de diciembre de 1677; BNM, Mss 2.289, fol. 161.

39 KaMEN, H., Op. cit, págs. 207-213. 
se consuma la moneda de molino y que se acuñen piezas pequeñas de plata para el comercio interior (reales de a dos, sencillos y medios reales), los cuales coexistirán con la calderilla y el vellón grueso, siempre que estos se utilicen en transacciones de poco valor ${ }^{40}$

Somoza y Quiroga no logró convencer a la «Junta de Moneda», reacia en modificar la valencia del oro y de la plata. Tal es así que ni siquiera en el informe elaborado el 13 de agosto de 1679, donde resume las opiniones de los hombres de negocios y demás personas consultadas, se alude para nada al Discurso y a los otros trabajos del citado arbitrista, cuyas ideas enlazan sin apenas distingos con las expuestas por Francisco Centani y Sebastián Muñoz Suárez. En efecto, la «Junta de Moneda» informa al soberano acerca de tres proyectos centrados de manera exclusiva en la moneda de molino. Uno de ellos contempla su total extinción, pues cualquier otra fórmula que se adopte acarrearía los mismos daños que se observan al presente. En lo que no se ponen de acuerdo quienes abogan por esta alternativa es si se debe dar o no satisfacción a los súbditos atendiendo al perjuicio que les ocasionará la retirada de dicha moneda de la circulación. La postura más radical se aviene en admitir que la moneda legítima, es decir, la que contiene mezcla de cobre y de plata, se recoja a cuenta de los débitos de los contribuyentes y otros deudores a la Real Hacienda _esta medida supondría un grave trastorno a los poseedores de moneda falsa, precisamente los menos favorecidos por la fortuna, sumiéndoles en la miseria-, mientras que la más moderada sostiene que se acepte también la falsa en el pago de las deudas al erario a fin de que los vasallos no sufran daño ninguno. El segundo proyecto que se somete a la "Junta» consiste en reducir el valor nominal de la moneda de molino falsa hasta igualarlo con el intrínseco, proporcionándolo además con el de la legítima en función de los valores de 1664. Finalmente, la tercera opción que se estudia - es la apoyada por la mayoría de los ministros- sugiere disminuir el poder liberatorio de la mo-

43 Somoza y Quiroga, A., Epitome de los premeditados puntos y compendiosa minuta a que se reduce el justificado y único medio de la moneda de oro, plata y vellón que con pronta y precisa ejecución necesita la Corona de Castilla... Madrid 1679, BNM. VE, 17/19, fols. $3,5,9,13$ y 17 . El contenido de este escrito es similar, salvo en algunos pequeños detalles, al Discurso de 1677 . Vuelve sobre el tema en Satisfacción nueva y evidente a las dificultades que se han discurrido sobre la fija estabilidad de la moneda de vellon... (BNM. Mss 9475, fols. 44-49), en Segunda satisfacción a las dificultades que nuevamente se han propuesto... (BNM, Mss 9475, fols. 35-39v) y en Reparos y conocidas conveniencias que se ofrecen tocantes al papel que tengo dado sobre la estabilidad y medios de la moneda de esta Corona (BNM, Mss 9475, fols, 40-43v). 
neda de molino, sin distinguir entre la falsa y la de ley por resultar imposible separarlas ${ }^{4 !}$.

De las tres alternativas, la tercera es la que suscribe la «Junta de Moneda" atendiendo a su viabilidad — la segunda es descartada por impracticable-y a que no origina tantos trastornos a los súbditos, a la economia y al Estado como la primera, pues la Corona no puede costear su retirada de la circulación según se encuentran sus finanzas y tampoco resulta oportuno suprimir de golpe siete millones de ducados, cantidad muy superior al numerario integrado por la calderilla y el vellón grueso que no superan los 5.700 .000 ducados; lo contrario supondria paralizar toda actividad mercantil con los daños que ello acarrearia al reino. En definitiva, la "Junta» recomienda devaluar la moneda de molino en un setenta y cinco por ciento, de manera que las piezas de ocho maravedies circulen con valor de dos maravedies y las de cuatro con el de un maravedi. De este modo, se dice en la consulta de 13 de agosto de 1679 ,

«Aunque quedará la moneda primitiva de ley con una tercera parte más de valor que la de vellón grueso, porque cincuenta y una piezas que entran en un marco hacen ciento y dos maravedies y el de vellón grueso vale setenta y la falsa feble con la mitad menos, es la porción que se le puede dar para irla acercando a lo justo en tanto que se consigue la igualdad de todas las monedas por el medio de la extinción: ${ }^{42}$.

La «Junta», que no renuncia a consumir la moneda de molino, como se desprende del último párrafo de la cita anterior, concluye proponiendo que la reforma se ejecute entre los meses de agosto y octubre, pues para entonces habrá Ilegado la Flota y los Galeones, y la reina -María Luisa de Orleans - estará ya en la Corte. El duque de Medinaceli es el único que discrepa de este sentir mayoritario. A su juicio, la moneda de molino debe suprimirse por completo ya que si no continuará entrando moneda falsa, dado que su valor nominal, aún cuando se devalue, seguirá siendo mayor que el intrinseco. Por lo que respecta a la fecha más idónea para emprender la reforma, es de parecer que se posponga tres o cuatro meses después de la arribada de la Flota y los Galeones. Su objetivo es que la moneda de plata procedente del comercio con América se pueda difundir en el reino en una proporción tal que sea capaz de sustituir a la que se retira ${ }^{43}$.

BNM, Mss 18.720, exp. 23. Consulta de la Junta de Moneda, 13 de agosto de 1679, fols.

42 Ibidem, fols. $2-2 v$ y 4

4.3 lbidem, fols. $6 \mathrm{v}-7$
} 
El vacio de poder que se produce a la muerte de don Juan José de Austria en septiembre de 1679 dilata la ejecución del proyecto durante varios meses, a no ser que aprovechándose de esta circunstancia el duque de Medinaceli haga valer ante el rey su propuesta dilatoria por las razones apuntadas. Por fin, el 10 de febrero de 1680 , once dias antes de ser nombrado primer ministro de la Monarquía el duque de Medinaceli ${ }^{44}$, Carlos II promulga una Pragmática que, en sintesis, recoge las ideas expuestas por la "Junta de Moneda»: reducir el valor nominal de la moneda de molino con liga de plata y la de vellón con igual peso de ocho a dos maravedies -en la misma proporción las restantes piezas-, y tasar en un maravedi toda la moneda falsa de cobre sin peso ${ }^{45}$. Para facilitar la retirada de esta moneda de la circulación, principalmente la legítima, se dispone que en las Cecas se reciban las piezas por el valor que tenían antes de la baja, pagándose su precio en oro o en plata con un cincuenta por ciento de premio al respecto de los 165 maravedies de liga de plata que tiene cada marco. Las monedas de cobre puro, por el contrario, sólo se aceptarán con su valor anterior a la Pragmática en satisfacción de deudas al erario de los años comprendidos entre el 1 de enero de 1674 y el 31 de diciembre de 1677 - los adeudos más antiguos se declaran cancelados-. Esta normativa será válida durante sesenta dias a partir de la fecha de publicación de la Pragmática; concluido este plazo, el pago de los impuestos y alcances, tanto de los pueblos como de los arrendatarios y hombres de negocics, se realizará con el valor nominal de la moneda resultante de la devaluación ${ }^{46}$. No obstante, al finalizar el plazo estipulado, se resuelve prorrogarlo por otros sesenta días desde el 10 de mayo de $1680^{47}$. Lo importante de esta disposición es que la Corona opta por sanear el sistema monetario, causa fundamental de la crisis económica de Castilla, según el sentir de los arbitristas y de los diplomáticos, como el embajador veneciano Federico Cornaro ${ }^{48}$, persiguiendo dos objetivos muy precisos: 1) combatir la inflación, de suerte que se modere «el precio de las mercancias y mantenimientos a la justa proporción que deben te-

\footnotetext{
${ }^{44}$ Según el comerciante saboyano Raimundo Lantery, el artifice de la reforma monetaria fue el duque de Medinaceli quien, para evitar las críticas, procuró que la Pragmática se publicase antes que su nombramiento como primer ministro (Un comerciante saboyano en el Cádiz de Carlos II. Las memorias de Raimundo de Lantery, 1673-1700, ed. de M. Bustos Rodriguez, Cádiz, sa, págs. 168-169)

${ }^{45}$ Nueva Recopilación. Auto XXIX, tít. XXI, lib V. La Pragmática la reproduce Garzón PAReja, M., La Hacienda de Carlos $1 /$, apéndice IV. Ver también Collantes Pérez-Arda, E. y Merino Navarro. J. P., Op. cit., pág. 79 y Hamilton, E. J., Guerra y precios..., pág. 43.

${ }^{46}$ Nueva Recopilación. Auto XXI, tit. XXI, lib. V, Capitulos 3 y 4

4 AGS, CJH, leg. 1.410. Real Decreto de 19 de mayo de 1680

48 Ver Relazioni di ambasciatori veneti al Senato, vol. X Spagna (1635-1738), ed. de Luigi Fripo. Turín 1979, pág. 456
} 
ner»; 2) dotar al reino de una moneda estable, garantizando a los súbditos "que en ningún tiempo pueda tener bajación la moneda que quedare» ${ }^{49}$.

\section{LA POLITICA MONETARIA DE 1680 A 1684}

El efecto inmediato de la Pragmática del 10 de febrero de 1680 fue el colapso del comercio por negarse los mercaderes y cosecheros a vender sus mercancias y frutos si se les pagaba con moneda devaluada, como lo pone de manifiesto, por ejemplo, el ayuntamiento de Montilla en una sesión celebrada el 14 de febrero. Esto obligará a la Corona a promulgar un bando estableciendo sanciones de veinte mil maravedies y veinte dias de cárcel para quienes se resistan a aceptar dicha moneda ${ }^{50}$. La segunda consecuencia, directamente relacionada con la anterior, fue que los precios experimentaron, de creer a Somoza y Quiroga, un alza espectacular, de tal modo que quien «sustentaba su familia con un real de a ocho hoy ha menester más de dos pesos" ${ }^{51}$. Algo de cierto hay en esta apreciación, si bien el encarecimiento de los productos no puede atribuirse únicamente a la deflación ni a la escasez de numerario que originó; el temor de la población, sobre todo de la urbana, a quedar desabastecida de alimentos básicos como el pan, el vino y la carne desempeñó un protagonismo destacado, coadyuvando a la subida. En este sentido cabe mencionar una normativa de la Sala de Alcaldes de Casa y Corte fechada el 11 de febrero prohibiendo a los madrileños salir de la ciudad para aprovisionarse del pan que traen los panaderos de los pueblos del contorno o adquirirlo fuera de la plaza y de las plazuelas, no permitiéndoles tampoco comprar más cantidad de la que hubieren menester, aplicándose a los infractores sanciones rigurosas ${ }^{\text {b? }}$. El concejo de Madrid a su vez trató de

\footnotetext{
${ }^{19}$ Asi aparece recogido en la Pragmática y en la Instrucción. Un ejemplar de esta última en AGS, CJH, leg. 1.407 y otro en AHN, Osuna, leg. 571 , exp. 5.

so AGS, CJH, leg. 1.411. Real Decreto de 29 de marzo de 1680; Calvo Poyato, J. "La última crisis de Andalucia en el sig!o Xv11: 1680-1685", Hispania XLVI, 164, 1986, pág. 525.

'Somoza y Quifoga, A. Señor, ei capitán... animado de las experiencias y zelo que le assiste en el servicio de V.M. y de la causa pública, dice..., BNM, VE, 17/20, fols. 3-3V. En otro memorial que puede atribuirse a este autor se expone lo siguiente: en tanto que se estudia su proyecto de tasar el real de a ocho en veinticuatro o veinticinco reales de vellón. se debe promulgar una Pragmática para que "debajo de graves y executivas penas" los alimentos y cualesquiera articulos de uso común "se vendan, troquen y transporten respectivamente a la reducción y cantidad de reales de plata que valian y pasaaban antes de la baja, bajando asimismo los derechos de los puertos y aduanas" (BNM, VE, 17/21, fol. 2).

AHN, Sala de Alcaldes, Libros de Gobierno. Año 1680. fol. 88.
} 
paliar la subida de los precios con una orden del mes de abril donde establecia una reducción sustancial en el valor de la carne, del vino y del aceite. El precio del pan, por otro lado, comenzó a descender, pasando de cincuenta y dos maravedíes las dos libras menos onza del mes de enero de 1680 a los treinta y cuatro maravedies a partir del 24 de febrero, tendencia que se mantuvo a lo largo del año, alcanzando los treinta maravedies en el mes de octubre ${ }^{53}$. En cuanto a las restantes mercancias, el cabildo municipal, en respuesta a una real provisión de 20 de julio encargando a los concejos ajustar los precios a lo razonable, elaboró un arancel que entró en vigor el 14 de diciembre, siendo modificado el 2 de mayo de $1681^{54}$. Lo propio acontece en otras ciudades. Asi por ejemplo, los ediles toledanos aprueban el 31 de agosto de 1680 una Moderación de precios que es publicada el 20 de septiembre ${ }^{55}$. Con todo, es muy probable que los vendedores procuraran soslayar el cumplimiento de tales disposiciones. A ello se refiere, de forma velada, un regidor de Madrid cuando advierte que «habiéndose mandado que todos los precios bajen no ha tenido esta santa ley observancia, estando el pueblo sin moneda y crecidos los abastos como si la hubiera, y esto se ve en la carne, en el aceite, en el jabón y en lo demás» ${ }^{56}$. Esto explica que la Sala de Alcaldes de Casa y Corte resolviera nombrar a tres alguaciles y otros tantos escribanos con el cometido de asistir a la plaza y supervisar que los comerciantes no expendieran los articulos a precios superiores a los estipulados en el arancel, deteniéndoles en este caso y obligándoles a devolver a los clientes estafados el dinero cobrado en demasía ${ }^{57}$. A mediados del mes de junio de 1681 todavia no se habían estabilizado los precios, según denuncia Antonio Solis en carta a don Alonso Carnero: "Este monstruo de la baja de la moneda engendró la premática; la premática la carestía de todas las cosas; y de la carestia nació el hambre que carece de ley y desarma a los legisladores ${ }^{58}$.

Los desórdenes provocados por la deflación del 10 de febrero de 1680 dieron lugar a nuevos memoriales de los arbitristas, como el escrito por el capitán Somoza y Quiroga al pocc tiempo de publicarse la Pragmática. En esta ocasión vuelve a plantear que se retire definitivamente la moneda

\footnotetext{
${ }_{53}$ Archivo de la Villa de Madrid (AVM), Secretaria, leg. 3-351-22.

34 AHN Conss, lib. 1.266, fol. 133 y lib. 1.474, fol. 19

5s Porres Martín-Cleto, J., "Política monetaria y precios en 1680: el caso de Toledo", Hacienda Pública Española, 87, 1984, págs. 155-197; Domínguez Ortiz, A., «La crisis de Castilla en 1677-1687", Crisis y decadencia de la España de los Austrias. Barcelona 1969, pág. 208. nota 22.

55: AVM, Libros de Acuerdos, 95, fol. 280

5HN, Sala de Alcaldes, libros de Gobierno. Año 1680, fol. 129.

54 Epistolado Español, I, BAE, tomo XIII, pág. 574a.
} 
de molino y se sustituya por otra de cobre "de peso y valor intrínseco", tasándose con uel equilibrio y correspondencia debido a la de oro y plata». Junto a esta medida propone una vez más que se asigne un valor facial superior a la moneda de plata, situando la cotización del real de a ocho en veinticinco reales de vellón - se cotizaba oficialmente a doce reales con el cincuenta por ciento de premio, aunque en la práctica, nos dice, éste oscilaba en torno al trescientos por cien--. Ejecutado su proyecto, la Corona conseguiria reducir el gasto que le supone retirar la moneda de molino, pues por veinticinco reales se abonaría sólo uno a los particulares, a parte de que le lograría abaratar los mantenimientos y evitar la saca de oro y de plata ${ }^{59}$. Su opinión, al menos la relativa a la moneda de molino, es compartida por el duque de Medinaceli y por un sector influyente de la administración que convence al rey de que la única alternativa viable que existe para sanear el sistema monetario es la de prohibir la moneda de molino. La Pragmática de 22 de mayo de 1680 es la respuesta a este planteamiento:

«Mandamos que toda la moneda de vellón de la fábrica de molinos que hay en estos reinos, asi la legitima con liga de plata que se labró en las Casas de Moneda de ellos, como también la falsa, fabricada de solo cobre dentro de ellos, y la feble que se ha introducido e introduce por los extranjeros y naturales, se prohiba el uso de ellas y que no corra por moneda con ningún valor desde el dia de la publicación de esta leys 60

El documento establece asimismo que las deudas contraidas con el fisco hasta 1678 se puedan cancelar en un plazo de seis meses en moneda de molino ligada a razón de ocho reales de vellón el marco. Esta medida deja inoperante lo resuelto en la Pragmática de 10 de febrero donde se acordaba que los particulares que la entregasen en las cecas serian retribuidos con doce reales el marco. Este cambio obedece, por supuesto, a la incapacidad del erario para afrontar semejante desembolso, como asi lo habia planteado el Consejo de Hacienda en una consulta del mes de abril: los veinte granos de plata que contiene cada marco de moneda de molino ligada valen, con el cincuenta por ciento de premio de la plata, 247,5 maravedies, y las siete onzas y tres ochavos de cobre de cada marco ascienden a 68 maravedies de vellón, todo lo cual suma nue-

5.3 Somoza y Quiroga, A. Señor el capitán..., BNM, VE, 17/20.

Nueva Recopilación. Auto $X X X$, tit. $X X \mid$, lib. V. Pragmática de 22 de mayo de 1680 y Auto $X X X \mid$, tit. $X X \mid$, lib. $V$. Instrucción dada el 22 de mayo de 1680; AHN Osuna, leg. 571, exps. 48 y 82 
ve reales y nueve maravedies por marco, produciéndose una pérdida para la hacienda de casi tres reales por marco, sin contar las derivadas de la fundición de la moneda ni los gastos ocasionados por los sueldos del personal de las cecas y por la acuñación del vellón grueso con la pasta de la moneda de molino de cobre puro. De aquí, en definitiva, que el Consejo de Hacienda proponga retribuir a los poseedores de dicha moneda a razón de 247,5 maravedies el marco, con lo que los particulares obtendrán una ganancia en el cambio menor que antes pero todavía bastante crecida respecto al valor en que fueron tasadas en la Pragmática del 10 de febrero. En esta consulta además se estima conveniente que los receptores, depositarios, fieles, recaudadores y administradores de rentas en cuyo poder estuvieran las cantidades recaudadas de los contribuyentes, así como cualesquiera deudores a la Corona por la adquisición de rentas, jurisdicciones y oficios, o por la media anata de mercedes, pueda saldar sus alcances hasta 1678 con moneda de molino ligada al precio de 247,5 maravedies el marco. De este modo, el Consejo de Hacienda juzga que no sólo obtendrán beneficio los vasallos, sino también el Estado, que podrá extinguir la mencionada moneda sin coste alguno y al mismo tiempo saldar con sus deudores cuentas atrasadas de difícil cobranza ${ }^{61}$.

Respecto de la moneda de molino de cobre puro con igual peso que la legítima, la Pragmética de 22 de mayo estipula que sus poseedores la ingresen en las Casas de Moneda en el plazo de diez dias, "con intervención de los superintendentes y contadores que hoy se hallan asistiendo a la labor de moneda gruesa" percibiendo al contado su importe a razón de dos maravedies la pieza de ocho - esto supone que se les abonan 204 maravedies por libra, dado que la libra son dos marcos y por cada marco se habia acuñado cincuenta y una piezas-, siempre que el monto total no exceda los quinientos reales, pues de ser asi se les darán vales a cobrar a los tres meses, y si supera los cien ducados se les endosarán vales que podrán hacer efectivos en un año en tres pagas de cuatro meses. Pasados los diez días de plazo sólo se abonarán las monedas de cobre regulándose a «148 maravedies la libra de diecisiete onzas, que es lo que corresponde a las treinta y siete piezas de a dos maravedies por marco a que hoy sale labrado cada marco en moneda nueva de todas las Casas de Moneda de esta Corte y de las demás del reino" ${ }^{62}$.

61 AGS, CJH, :eg. 1.410. Consulta del Consejo de Hacienda, 2 de abril de 1680.

6.2 Nueva Recopilación. Auto XXX, tít. XXI, lib. V. Pragmática de 22 de mayo de 1680. 
Con la retirada de la moneda de molino se intentaba evitar la tesaurización, denunciada desde el instante mismo que se devaluó ${ }^{63}$. Este objetivo justifica tambiér que ahora se autorice a los particulares fundirla y vender la pasta por su cuenta, lo cual, según Raimundo Lantery, reportó ganancias estimables a quienes la adquirieron para extraerla del país, motivo que lleva a la Corona a decretar, tras consulta del Consejo de Castilla, que se observe lo dispuesto en las leyes del reino sobre saca de plata y que los corregidores de las ciudades portuarias supervisen que los comerciantes españoles que entran géneros de fuera los abonen con mercaderias nacionales, enviando cada seis meses relaciones de lo obrado bajo multa de cincuenta mil maravedies y apercibimiento ${ }^{64}$. Con todo, la escasez de numerario en 1680 fue un problema endémico para los gobernantes, no digamos ya para los agricultores, artesanos y comerciantes, que se trató de solucionar acuñando moneda de plata y de vellón. El 9 de agosto de 1680 el Consejo de Hacienda discurrió labrar sin demora piezas pequeñas de plata en cantidad de trescientos mil reales de a ocho, a cuyo efecto se despacharian órdenes al Consulado de Sevilla y al Consejo de Indias, «para que se obligue a los compradores de plata de Sevilla a que remitan [...] las barras y pasta de plata que son menester para esta labor, y que al mismo tiempo se de disposición en las mismas casas de Moneda para que se labre la plata de vajillas que se llevare de los particulares, libre de derechos de señoreaje» ${ }^{65}$. El proyecto, ciertamente, se ejecutó, pero no sabemos si se acuñó la cantidad prevista, por otro lado insuficiente para reactivar el comercio, como tampoco parece ser que animara a los inversores una resolución del 31 de julio de 1680 por la cual se les aseguraba que los intereses de los préstamos concedidos serían reintegrados en la misma moneda en que fueron realizados, es decir, en plata o en vellón, según lo estipulado en los contratos ${ }^{66}$. Con la moneda de cobre sucede otro tanto: quienes la poseen se resisten a desprenderse de ella aguardando una ocasión mejor, incluidos los receptores, depositarios y tesoreros de los partidos, a quienes se conmina el 3 de agosto de 1680 a entregar toda la moneda de molino que tengan y obtener despachos por dichas sumas, una vez registradas, siendo de su cuenta la pérdida de la baja en caso de no cumplir la requisitoria ${ }^{67}$. Por eso, inmediatamente después de la deflación del 10 de febrero de 1680 se procedió a labrar piezas de vellón con valor de dos maravedies. Ig-

63 Calvo Porato, J., Op. cit., pág. 526.

i. Nueva Recopilación. Autos XXX y XXXI, tit. XXI, lib. V; LANTERY, R. DE, Op. cit, pág. 169

65 AGS, CJH, legs. 1.403 y 1.410. Consulta de Consejo de Hacienda, 9 de agosto de 1680 .

6i Ibidem, leg. 1.410. Consulta del Consejo de Hacienda. 31 de julio de 1680

Ibidem, lib. 304. Real Cédula de 3 de agosto de 1680. 
noramos la fecha exacta en que comenzó a acuñarse esta moneda, pero todo apunta a que fue con anterioridad a la Pragmática de 22 de mayo de 1680 , con lo que yerran quienes afirman - Heiss, Gil Farrés, por ejemplo-- que se produjo a raíz de la citada ley, confundidos tal vez por el artículo diecisiete de la Instrucción que acompaña a la Pragmática aludida, en donde se expone que la moneda de molino retirada se fundirá y con su pasta se tallará vellón grueso con valor de dos maravedies la pieza ${ }^{68}$. Confirma nuestra creencia una consulta del Consejo de Hacienda fechada el 22 de abril pues en ella se menciona ya esta acuñación, propuesta el 22 de febrero por el tesorero de la Casa de Moneda de Granada y el 24 de febrero por el Consejo de Castilla, con varios informes de los ensayadores Bernardo de Pedreira y Manuel Mayers ${ }^{69}$. Por cierto, que en estos informes se aconsejaba labrar treinta y ocho piezas por marco, medida al parecer aprobada por el monarca, si bien en la práctica sólo se tallaron treinta y siete piezas por marco, como asi se desprende de una consulta del Consejo de Hacienda de 2 de junio de $1683^{70}$, la misma talla que se menciona en la Pragmática e Instrucción de 22 de mayo de 1680.

Los esfuerzos de la Corona por poner en circulación mayor cantidad de plata y de vellón e impedir que la existente fuera acaparada no tuvieron el éxito que los ministros se prometían. El 12 de octubre de 1681 el Consejo de Hacienda constataba todavia que el trueque de productos era habitual en varias comarcas, de donde se seguia la necesidad de acuñar más moneda ${ }^{71}$. Es muy probable que la provisión realizada por los asentistas en dicho año de 1.268.229 escudos de vellón y de 1.109 .393 escudos de plata, agotase el numerario disponible. De hecho, entre 1682 y 1684 el país está casi totalmente desmonetarizado, tal como lo refleja el volumen de las provisiones de los asentistas en este periodo ${ }^{72}$ y las dificultades del Estado para obtener plata —en 1682 se perdió parte de la plata que traía la Flota de Indias- y cobre con los que acuñar reales sencillos, medios reales y piezas de dos maravedies. Con el tiempo, la situación empeoró al producirse una subida en el precio del cobre, pasando de un

\footnotetext{
68 HeIss, A., Monedas hispano-cristianas. Madrid 1865, pág. 200 (reimpreso en Madrid 1975): Gll Farres, O.: Historia de la moneda española. Madrid 1959, pág. 244. Collantes Pérez-Arda y Merino Navarro apuntan algunas razones más para explicar que la acuñación de monedas de cobre de dos maravedies fue anterior al 22 de mayo de 1680 (op. cit., págs. 81-82).

${ }^{69}$ AGS, CJH, leg. 1.411. Propuesta del tesorero de la Casa de Moneda de Granada, 22 de tebrero de 1680; Collantes Pérez-Arda, E. y Merino Navarro, J. P., Op. cit., 81-82.

AHN, Conss, leg. 51.360, exp. 77; AGS, GJH, leg. 1.457. Consulta del Consejo de Hacienda 2 de junio de 1683

AGS, CJH, leg. 1.425. Consulta del Consejo de Hacienda, 12 de octubre de 1681.

ir Sanz Ayan, C., Op. cit., pág. 494.
} 
real y medio de vellón el marco en 1680 a un real y tres cuartos de vellón el marco en 1683 - para Frank C. Spooner, el año 1680 coincide con un veinte por ciento de baja en el precio del cobre, culminando así una tendencia que venia observándose desde los años finales de la década de los setenta y que se prolongará en los primeros años de los ochenta ${ }^{73}$-.. Es muy significativo al respecto que el 2 de abril de 1683 el Consejo de Hacienda envie una circular autorizando a los superintendentes y administradores de los partidos recibir de los contribuyentes bacias y otros objetos de cobre a razón de un real y cuarto de vellón el marco, aunque según el marqués del Castillo, dicho precio es excesivamente bajo y «me recelo fructifique poco [...], con la circunstancia de haber de llevar el cobre a las Casas de Moneda» ${ }^{74}$. Los temores del ministro debieron de confirmarse, pues el 14 de mayo de 1683 una pragmática establece que el marco de cobre se adquiera a un real y tres cuartos de vellón el marco, permitiéndose además a los vasallos cancelar sus deudas con el erario hasta 1682 con objetos de cobre. Simultáneamente se decreta el embargo de todo el metal que estuviera en poder de los caldereros y se prohíbe fabricar enseres de uso doméstico con dicho metal, empleándose en su lugar hierro procedente de Liérganes y La Cavada o Vizcaya, idea ya sugerida por el marqués del Castillo- ¿se pretende con esta medida potenciar dicha industria, muy decaída en la etapa 1680-1686? ${ }^{75}$-, fijándose penas a los infractores que iban hasta la pérdida de la mitad de sus bienes y destierro a perpetuidad ${ }^{70}$. La orden, sin embargo, tuvo que ser revocada ante las protestas de los caldereros, optando la Corona, en su atán de labrar dos millones de ducados en moneda de vellón, por abastecerse de cobre en el extranjero ${ }^{7 \overline{ }}$, toda vez que resultaba imposible abonar tres reales y tres cuartos de vellón por marco de cobre, según se reconoce en un decreto del mes de junio de 1683, donde se estipula que el cobre de los caldereros y demás personas se compre a tres reales y medio de vellón el marco ${ }^{78}$.

En cuanto a las piezas que se deben acuñar por marco de cobre, una real orden dirigida a! Consejo de Hacienda viene a plantear la conve-

3 Spooner, Frank. C. L'économie mondiale et les frappes monétaires en France, 14931680. París 1956, pág. 45; Gl AmANn. K., «El comercio europeo (1500-1750)», Historia económica de Europa (2). Siglos xw y xvit. Barcelona 1979, págs. 388-389. 1683.

AGS, CJH, leg. 1.445. Correspondencia del marqués del Castillo, 2 y 24 de junio de

is Alcala Zamora y Queifo df Llano, J., Historia de una empresa siderúrgica española: los altos hornos de Liérganes y La Cavada, 1622-1834. Santander 1979, pág. 95.

16 Nueva Recopilación. Auto XXXII, tit. XXI, lib. V. Pragmática de 14 de mayo de 1683

Dominguez Ortiz. A., Op. cit., pảg. 209

18 AGS, CJH, leg. 1.445. Correspondencia del marqués del Castillo, 13 de mayo de 1683. 
niencia de que se aumenten a treinta y nueve para compensar los gastos, ya que sólo podrá evitarse la pérdida que representa la talla de piezas de dos maravedies si se labran cuarenta y una piezas por marco - lo ajustado del coste de las treinta y siete piezas por marco se desprende de los cálculos elaborados y presentados al Consejo de Castilla en 1680 por Bernardo de Pedreira ${ }^{79}$ - El Consejo de Hacienda, empero, se opuso a esta medida, máxime cuando el criterio adoptado en 1680 de labrar treinta y siete piezas por marco fue el de igualar esta moneda a la que ya estaba circulando - ise refiere a la de molino deflacionada o a otra acuñación, tal vez decretada en 1677 bajo el gobierno de don Juan José de Austria, paralela a la realizada en dicho año en el reino de Navarra? ${ }^{80}$ - para que pudieran correr mezcladas en el comercio sin distinción. Aparte de esto, si ahora se tallan treinta y nueve piezas por marco, asegura el Consejo de Hacienda, «aunque sea con la calidad rigurosa de la permisión de una sola pieza de feble [...] resultará tan considerable diferencia en el peso como de cinco libras y media en cada talego de 500 reales de una moneda a otra, y una libra y dos onzas de cada cien reales con que se deroga la primera resolución, tan acertada que hasta hoy, con lo que la experiencia ha mostrado en el discurso de cuatro años, no se ha experimentado ningún inconveniente» ${ }^{81}$. En suma, el Consejo trata de evitar que los súbditos atesoren la moneda de mayor valor intrínseco porque con ello se agudizará más todavia la falta de numerario en circulación y se cometerán introduciones de moneda falsa, de menos peso, creciendo el premio de la plata, fenómeno que se pretendía eliminar con la Pragmática del 10 de febrero de 1680. Sus argumentos no fueron rechazados, pues prosiguieron acuñándose treinta y siete piezas por marco hasta que el 30 de junio de 1685 se suspendió temporalmente la talla ${ }^{82}$. En la práctica, sin embargo, el peso teórico de estas piezas (6,2 gramos) fue rebajado casi en un diez por ciento para así rentabilizar mejor el coste de la acuñación ${ }^{83}$.

\footnotetext{
79 Collantes Pérez-Arda, E. y Merino Navarro, J. O., Op. cit, pág. 83.

so Ibidem, pág. 82.

${ }^{81}$ AGS, CJH, leg. 1.457. Consulta del Consejo de Hacienda, 2 de junio de 1683; AHN, Conss, leg. 51.360, exp. 77.

82 AGS, CJH, leg. 1.480. Real Decreto de 30 de julio de 1685, mencionado en una consulta del Consejo de Hacienda del 12 de octubre de 1685.

${ }^{83}$ Collantes Perrez-Arda, E. y Merino Navarro, J. P., Op. cit., págs. 90-91
} 
NUEVAS PROPUESTAS ARBITRISTAS Y REHABILITACIÓN DE LA MONEDA DE MOLINO

La retirada de la moneda de molino y su sustitución por otra de cobre con valor de dos maravedies la pieza, junto con la escasez de numerario en todo el reino, incluido el oro y la plata que permanecen retraídos -así lo refiere el Consejo de Hacienda en 31 de julio de $1681^{84}$ - , alentó a los arbitristas a proponer soluciones que concluyesen con el caos monetario en el que estaba sumida Castilla. En general, la mayoria de los memoriales consultados se pronuncian a favor de crecer el valor nominal de la plata frente al vellón y de acuñar moneda pequeña de plata para el comercio interior de poco volumen.

En un escrito remitido al Consejo de Castilla el 22 de junio de 1680 , al mes justo de haberse promulgado la Pragmática que suspendía la moneda de molino, el capitán Somoza y Quiroga, tras denunciar el descrédito de los ministros por no haber aprovechado una ocasión sin precedentes, cual fue la llegada a la península de más de veinte millones de pesos en plata -el dato es confirmado por Kamen- del comercio de Galeones, Flota y azogues para fabricar reales sencillos y medios reales de plata y retirar todo el vellón sin agravio de los vasallos, propone una vez más la subida de los reales de a ocho, aconsejando que se tasen a veintiséis reales de vellón, y la fabricación de moneda pequeña de plata en la ceca de Segovia con doble valor que el intrinseco. Si se rechazan estas medidas sugiere entonces mantener el real de a ocho con valor de doce reales de vellón -es el premio oficial de la plata-, siempre y cuando los ochavos valgan un maravedí - se tasaron en dos- y la calderilla un cuarto de su valor. En el supuesto de que tampoco se admita esta propuesta es partidario de que se acuñe vellón con la condición de que por cada libra de cobre se hagan dos reales de ochavos o maravedies, "que es el justificado precio de la seis libras de moneda de cobre que deben corresponder a cada onza de plata». Esto implica, por tanto, labrar sesenta y ocho piezas de dos maravedies por marco de cobre en lugar de treinta y siete, con lo que el valor intrínseco de cada una sería la mitad de su valor nominal con poca diferencia ${ }^{85}$. En esta línea se inscribe el memorial Arbitrio politico sobre la moneda. Su autor, enmascarado en el anonimato, o al menos asi se nos presenta al lector del siglo $x x$, aparte

34 AGS, CJH, leg. 1.425. Consulta del Consejo de Hacienda, 31 de julio de 1681.

85 Somoza y Quiroga, A., Señor, el capitán..., BNM, VE, 17/20 y Único desengaño y perfecto remedio de los menoscabos de la Corona de Castilla y de general alivio de todos sus vasallos... 1680, en Semanario Erudito. Madrid 1787, vol. XI, págs. 225-256. 
de recomendar que la moneda en circulación sea exclusivamente de oro y de plata, ajustándose la de Aragón, Valencia y Cataluña a la castellana -es uno de los raros arbitrios que defienden un sistema monetario único para el conjunto de los reinos peninsulares-, dejando la calderilla, tarjas y ochavos antiguos de cobre para el comercio "de menudo", aboga por que se acuñen reales de plata con valor de dieciséis reales de vellón y doblones con valor de sesenta y cuatro reales de plata, excusándose el premio - la propuesta viene a legalizar un premio para la plata del cien por cien- ${ }^{86}$.

En 1681, don Pedro de la Maza Puente, de la Contaduría Mayor de Cuentas, plantea medidas similares a las de Somoza y Quiroga y, antes de él, de Francisco Centani, fray Juan de Jesús y Sebastián Muñoz Suárez: los reales de a ocho deben subirse a diez reales de vellón y en la misma proporción el oro, quedando la diferencia en beneficio de los vasallos, pues sólo asi se incentivará el comercio —el plan será ejecutado en 1686, como luego veremos-. Para combatir la escasez de numerario sugiere que se labren «dos millones de vellón [...] en ochavos del mismo valor y peso que hoy tienen» ${ }^{87}$. Dos años después, Juan de Arizmendi suscribe el dictamen de Somoza y Quiroga - no hemos encontrado memoriales de este autor posteriores a 1680, lo que nos lleva a suponer que debió fallecer en los primeros años de la década de los ochenta-: teniendo en cuenta, nos dice, que los extranjeros acuñan nuestros reales de a ocho con un poder liberatorio de diez reales, solicita que se tasen en veinticinco reales de vellón y a su tenor la moneda de oro. No obstante, si esta reforma se juzga escandalosa y desproporcionada o inviable, aconseja que el real de vellón se cotice en ochenta maravedies, dejando el real de a ocho en doce reales de vellón, pues «cuanto menos vale la plata menos renta percibirá» la Corona. Su pensamiento no sólo se encamina a establecer una relación justa entre la plata y el cobre, sino también, como lo especifica en otro escrito fechado en 1683, a adecuar los valores intrínseco y extrinseco de las monedas, ya sean de plata, de oro o de vellón para que de este modo ni se acaparen ni se falsifiquen ${ }^{88}$.

${ }^{36}$ BNM, MSs. 6.731, fols. 39-42.

- Maza Puente, Pedro de la, Parecer que dio... sobre los puntos que contiene este papel en 14 de octubre de 1681, considerando el estado de la Monarquía y el mayor servicio del Rey Nuestro Señor, BNM, Mss 19.700/29.

${ }^{38}$ AfizMENDi, Juan, Breve compendio de las sabidas verdades donde se descubren las principales causas de minorarse las Reales rentas y los remedios que se pueden aplicar. Cádiz 1682, BNM, VE, 24/25, y Breve resumen que declara con evidencia no ser caudal permanente en los reinos de Castilla el oro y la plata, y pruebase serlo el vellón. Puerto de Santa María, septiembre de 1683, BNM, VE, $199 / 57$. 
Durante el año 1683 el volumen de memoriales remitidos al Consejo de Castilla aumenta notablemente. Este flujo obedece, con toda seguridad, a la grave situación económica que se abate sobre el reino, originada por la baja de la moneda así como por la crisis de la agricultura, relacionada con malas cosechas, y por la mortalidad tan elevada que padecen muchos lugares entre 1677 y $1682{ }^{89}$. De todos los escritos de esta fecha que hemos consultado, el más interesante es el elaborado por el abogado de los Reales Consejos y del Secreto del Santo Oficio de la Inquisición, don Juan Sánchez de Urive y Salazar. Aunque reconoce la acertada providencia de retirar la moneda de molino, no deja de advertir lo "yertos" que han quedado los reinos, «sin oro ni plata ni vellón para las transacciones comerciales, de suerte que los géneros no se venden ni hay quien los compre ni a ínfimos precios" "9. Ante este problema, su consejo es acuñar moneda de plata menuda, recurriendo incluso a las vajillas y preseas de la nobleza o de cualquier súbdito acaudalado, ya que la tesaurización privada únicamente conduce al emprobrecimiento general del país:

"el dinero fomenta el comercio, mantenimiento, vida y causa segunda. Sus accesiones civiles rinden más que frutos naturales, artes $y$ industrias. Con él se tienen todas las cosas. Redime las necesidades públicas y particulares, aumenta el Real Tesoro, paga, es liberal y da exención de nuevos tributos, indecencias, empeños, usuras, pleitos, cárcel, gastos, hostilidades y daños privados. Ennoblece al plebeyo, da honor y lustre y engrandece al reino. Es sangre, espíritu y ánima de los mortales, nervio de la paz y de la guerra, urna de las cuatro bienaventuranzas del mundo. Da mérito con Dios. Vale más para los hombres que el reino del Cielo. Cristo, Señor Nuestro, en cuanto hombre le obedeción ".

El texto es harto elocuente de lo que numerosas personas opinaban a finales del siglo XVII, sobre la bondad del dinero y los desastres o desgracias que su falta causaba a los hombres, a los pueblos y a los Estados, si bien pocos son tan explicitos como nuestro abogado-arbitrista. Pero si conviene desatesorar al capital privado -resaltemos que en ningún momento hace referencia al que estaba en manos de la Iglesia- para que fluya en el seno de la colectividad produciendo riquezas -en 1684 otro

89 Dominguez Ortiz, A., Op. cit., págs. 200-206; Calvo Poyato, J., Op. cit., pág. 527-538; KaMEN, H., Op. cit, págs.

90 Sanchez de Ufive y Salazar, Juan. A la Sacra, Católica, Real Majestad del Rey Nuestro Señor... Memorial y Discurso politico de la moneda, 28 de marzo de 1683, BNM, VE, 24/40, fols. 6-8.

91 Ibidem, fol. $8 \mathrm{v}$. 
arbitrista recomendará asimismo que se labren las joyas particulares, con excepción de las utilizadas en el culto divino, lo que supondrá incrementar el numerario en circulación y el fomento de la industria alfarera, tan excelente en el reino como la de Úbeda, Baeza y Talavera ${ }^{92}$ - es preciso además que se evite su extracción. Por este motivo aconseja equiparar la ley de la moneda de plata a la que está en vigor en Europa, bajando su valor intrínseco y subiendo el nomirial. La nueva ley de las monedas que se acuñen deberá ser de diez dineros y diecisiete y medio granos - -sugiere, por lo tanto, rebajar la existente en diez granos y medio-, tallándose 134 piezas por marco. Las piezas labradas serán de cuatro cuartos (dieciséis maravedies) y se tasarán en seis cuartos de vellón (veinticuatro maravedies), con el premio reconocido del ciento cincuenta por ciento. Una vez labrada esta moneda nueva se retirarán los reales de a ocho y de a cuatro para rebajarles la ley y adaptarles a la nuevamente establecida. Por lo que respecta a la moneda de cobre, sostiene que sólo pueda utilizarse en aquellos pagos que no sobrepasen los dieciséis maravedies ${ }^{93}$.

Los arbitrios restantes que se escriben entre 1683 y 1684 apenas aportan nada nuevo digno de mención. La idea más común, como ya indicamos al inicio de este apartado, es la subida del valor de la plata. Así, unos proponen que se duplique y otros que se tase con la mitad más de su cotización actual. Todos, también, son partidarios de que se acuñen reales de plata sencillos y medios reales y algunos, como Álvarez Osorio y Redin, en su Discurso Universal, desaconsejan que se labre vellón ${ }^{94}$.

Esta corriente de opinión contrasta con la expuesta en diversas consultas de los Consejos de Castilla y de Estado a tenor de un Real Decreto de 19 de noviembre de 1683, en el que el monarca encarga discurrir «los remedios que puedan aplicarse a este daño que nos va reduciendo al último extremo». Los consejeros de Castilla no lograron emitir un dictámen aprobado por la mayoria y optaron por responder con votos particulares. Dejando a un lado cuestiones relacionadas con la guerra y los apuros financieros de la Corona, el sentir común fue que no debía acometerse la subida de la plata -la única voz discordante fue la de don Alonso Márquez de Prado-. Mayor desacuerdo hubo en lo que se refiere a la moneda de molino. Don Antonio de Monsalve, exgobernador del Con-

${ }^{22}$ BNM, VE, 25/92, fol. 10V.

93 Sanchez de URive y Salazar, J., Op. cit., fols. 10-13v, 19, 20-21.

${ }_{94}$ British Library, Egg 339, fol. 347; BNM, VE, 25/92, fol. 11; BNM, mss, 6.731, fols. 1-10; Alvarez Osorio y Redin, M., Discurso Universal de las causas que ofenden esta Monarchia... BNM, Mss. 6.659, fols. 111-159. 
sejo de Hacienda, se pronunció a favor de rehabilitarla por ser «la mejor que se ha labrado", en lo que fue secundado por don Martín Beltrán, solicitando en consecuencia que volviese a ponerse en circulación, dando el valor de un cuarto a la de dos cuartos y manteniendo la proporción en las demás piezas - se propugna que las piezas antiguas de ocho maravedies se tasen en cuatro maravedies, duplicándose la cotización que había quedado fijada en la Pragmática de 10 de febrero de 1680-; otros ministros, por el contrario, juzgaron por bien resuelto la retirada de la moneda de molino. Tal disparidad de opiniones debió sumir en la perplejidad al duque de Medinaceli, optando finalmente por continuar la acuñación de moneda de cobre ${ }^{95}$.

La actitud del gobierno de no introducir cambios en el sistema monetario y proseguir las directrices marcadas en la Pragmática de 22 de mayo de 1680 es revisada el 21 de agosto de 1684 por una Junta especial reunida a raiz de un Real Decreto de 26 de julio, ya que plantea con crudeza la ineficacia de los medios aplicados hasta entonces: 1) la escasez de cobre ha ralentizado la fabricación de moneda de vellón, lo cual nos induce a pensar que no pudo adquirirse del extranjero en cantidad suficiente y que tampoco dio fruto la orden expedida por la Corona para que los particulares entregasen en las cecas sus enseres de cobre; 2) las piezas labradas en la Casa de Moneda de Segovia han desaparecido de la circulación; 3) el llamamiento a los vasallos para que amonedaran su plata no ha tenido las repercusiones que se esperaban. La conclusión del informe es que los súbditos, sin dinero, no pueden abonar las rentas reales y mucho menos aún los censos, cuyos intereses no habian sido rebajados ${ }^{96}$. No estamos ante un documento alarmista, pues las penalidades de los pueblos quedan reflejadas en los memoriales que envían al Consejo de Hacienda, aún cuando sus quejas no siempre sean objetivas, y en la correspondencia de los superintendentes y administradores de los partidos. Asi lo representa, por ejemplo, Villanueva de los infantes (Ciudad Real) en 1682: sus habitantes, con la baja de la moneda, no han podido pagar el principal y los intereses de los créditos tomados en años anteriores para cultivar sus tierras, lo que les ha precisado a «dejar la labor y perder las viñas, y otros se han ausentado" "27. El descenso de los precios, por otro lado, si benefició a los consumidores, perjudicó a los cosecheros y artesanos. Según Hamilton, tomando como base cien el período 1671-1680, los indices de los precios de las dos Castilla y Andalucia

\footnotetext{
${ }^{35}$ AHN, Conss, leg. 51.360, exp. 75.

96 Dominguez Ortiz, A., Op. cit., pág. 213.

93 AGS, CJH, leg. 1.435. Consulta del Consejo de Hacienda, 23 de mayo de 1682.
} 
descendieron respectivamente en un 37,42 y 34 por ciento en el quinquenio 1681-1685; tendencia confirmada por Gutiérrez Alonso para la ciudad de Valladolid: comparando los precios del período 1681-1685 con el precedente de 1676-1680, éstos cayeron en un 42 por ciento para los cereales, en un 41 por ciento para el pan, en un 44 por ciento para el vino y en torno al 40 por ciento para la carne ${ }^{98}$. Precisamente, a esta causa atribuyeron algunas villas la miseria de sus vecinos y la despoblación, como Alcaudete de la Jara (Toledo), Manzanares (Ciudad Real) Altarejo y Valera de Abajo, en Cuenca ${ }^{99}$. El encabezamiento general del reino, propuesto el 25 de mayo de 1680 para combatir los efectos de la deflación de la moneda de molino, reiterado por el Consejo de Hacienda el 12 de octubre de 1681, fecha en la que fue aprobado por el monarca, aunque su ejecución se pospuso hasta diciembre de 1682, favoreció, sin duda, a los vasallos por las rebajas otorgadas en los impuestos y en los débitos, pero no en la medida deseada. El auge del fraude fiscal en estos años es la consecuencia lógica del descontento de una parte de la sociedad, especialmente la nobleza media de las ciudades y el clero, regular o secular, así como los soldados, mal retribuidos, y los criados de la aristocracia, con la politica monetaria adoptada por la Corona ${ }^{100}$.

Urgía, por lo tanto, buscar soluciones que dieran resultados más óptimos que los hasta ahora tenidos, pero la empresa no era fácil. La diversidad de opiniones que provocaba entre los ministros el ajuste del sistema monetario queda reflejada fielmente en una consulta del Consejo de Estado remitida al de Castilla para su estudio. Según unos, rehabilitar la moneda de molino con el valor que tenia antes de la Pragmática de 10 de febrero de 1680 ofrecia menos inconvenientes que cualquier otro arbitrio, sobre todo si a la vez se aumentaba la cotización de la plata en un cien por cien; para otros, en cambio, no era aconsejable modificar la relación plata-vellón si se rehabilitaba la moneda de molino; hay ministros que abogan por que la moneda de molino circule de nuevo aunque con valor de cuatro y dos maravedies, legalizando el premio de la plata que está en vigor; los hay, también, que arremeten contra la acuñación de piezas de cobre, mostrándose propicios a labrar moneda pequeña de plata; un quinto grupo prefiere que se siga acuñando piezas de cobre de dos maravedíes, sin introducir más innovaciones; y por último, otro sector

\footnotetext{
${ }^{98}$ Gutiérrez Alonso, Adrián, Op. cit., pág. 170; Hamilton. E. J., Guerra y precios..., págs. 273-284.

${ }_{99}$ Dominguez Ortz. A., Op. cit., págs. 215-216.

100 SÁnchez BelÉN, J. A., "Absolutismo y fiscalidad en Castilla a fines del siglo XVII: E! encabezamiento general del Reino (1682-1685)", Espacio, Tiempo y Forma, serie IV, 2, 1989, págs. 175-218.
} 
apoya el uso de la moneda de molino con valores de cuatro y dos maravedies pero sin alterar la tasa de la plata. A tenor de esta consuita, y después de un examen minucioso de las propuestas formuladas, el Consejo de Castilla se manifiesta unánimemente a favor de rehabilitar la moneda de molino y labrar reales sencillos y medios reales con la plata procedente de América, a lo que se aviene el monarca. La pragmática del 9 de octubre de 1684 ratifica este acuerdo. Por ella se pone de nuevo en circulación la moneda de molino legítima, tasándose la pieza mayor en cuatro maravedies -equivale a seis reales el marco de plata frente a los doce que tenía antes del 10 de febrero de 1680 -, se prohíbe extraerla del reino y se mantiene en vigor la suspensión de la moneda de molino falsa ${ }^{101}$.

\section{LA INFLACIÓN DE LA PLATA EN 1686: LA ESTABILIDAD DEL SISTEMA MONETARIO}

Para algunos autores, rehabilitar la moneda de molino legitima carece de sentido por cuanto que el poder liberatorio dado en 1684 es muy inferior al intrínseco (204 maravedies por marco frente a 302,5 maravedies que es su valor real), lo que conllevaba, a largo plazo, a confundirse con la moneda falsa desapareciendo del circuito comercial sustituida por ésta ${ }^{102}$. $Y$ tienen razón sin duda. No obstante, la medida venía a paliar la escasez de numerario, bestia negra en aquellos años de la economía castellana, y dar un respiro a los vasallos en sus penalidades. Con todo, hay que decir que el gobierno no cesa, entre tanto, de buscar otras vías que estabilicen definitivamente el sistema monetario: los proyectos presentados por los arbitristas en los años 1680-1684, asi como los planteados tiempo atrás por Francisco Centani, Sebastián Muñoz Suárez y demás habian dejado una huella profunda en algunos consejeros, predisponiéndoles a subir el valor nominal de los reales de a ocho respecto del vellón en la proporción conveniente al premio de la plata. Suponemos que los ministros de Carlos II no eran conscientes de que cualquier revalorización facial de la moneda, si coincide con un aumento del gasto público, con la presión de determinados sectores económicos interesados en la inflación de beneficios o con el desequilibrio de la balanza de pagos, genera un

\footnotetext{
101 AHN, Conss, leg. 51.360, exp. 77; Nueva Recopilación, Auto XXXIII, tit. XXI, lib. V. Pragmática de 9 de octubre de 1684.

${ }^{302}$ Collantes Pérez-Arda, E., y Merino Navarro, J. P., Op. cit, págs. 87-88.
} 
proceso inflacionista ${ }^{103}$, pero lo cierto es que su resistencia a subir el valor facial de los reales de plata parece tener en cuenta dicho principio. Hay que tener presente que la deuda pública habia alcanzado tal nivel que desde 1669 se adoptaron diversos expedientes para reducirla a unos límites aceptables, aun a costa de sus titulares, lo que se practicó también con los gastos derivados del gobierno de la Monarquía, y que la balanza de pagos se saldaba siempre a favor de Gran Bretaña, Francia, Holanda y Génova, cuyos mercaderes estaban interesados en que el valor de la moneda de plata castellana, muy ajustado al intrínseco, no se alterase, pues los márgenes de ganancia obtenidos disminuirian al bajarse la ley: si esto sucedia, el comercio internacional podria reducir sus exportaciones hacia Castilla, encarecer los precios, solicitar descuentos aduaneros o desviarlo directamente hacia América, todo lo cual repercutiría al final en la actividad económica de los españoles y en el abastecimiento de la Monarquía.

La pertinaz actitud del Consejo de Castilla en conservar la moneda de plata con un bajo valor nominal no es, en definitiva, un capricho ni tampoco consecuencia del inmovilismo o la desidia. En torno a 1684 pocos ministros veían oportuno revalorizarla y asi lo manifestaron. Dos años después, sin embargo, el conde de Oropesa, sucesor del duque de Medinaceli, adopta este procedimiento dando satisfacción a cuantos venían solicitándolo desde el comienzo del reinado. El interrogante que se nos plantea es el de por qué en 1686 se resuelve aplicar una subida al valor de la plata y del oro. La respuesta no es sencilla, aunque varios factores pudieron contribuir a semejante decisión: $1^{\circ}$ ) estabilidad de los precios; $\left.2 .^{\circ}\right)$ afluencia en el mercado de una cantidad mayor de moneda gracias a las acuñaciones que se vienen realizando desde 1680 , a la puesta en circulación de la moneda de molino ligada y a los caudales procedentes de América, en particular los que arribaron en 1686, de los cuales 1.232.086 pesos iban destinados a la Corona y 30.000 .000 a particulares ${ }^{104} ; 3^{\circ}$ ) recorte del gasto público (se suspenden las mercedes que venian concediéndose, salvo las percibidas por viudas y soldados «estropeados») y de la deuda consolidada o juros, al menos la situada sobre los cuatro unos por ciento y los millones acrecentados en tiempos de Felipe IV -en el primer caso porque el impuesto se rebaja a la mitad; en el segundo, porque cesa totalmente- ${ }^{105} ; 4^{\circ}$ ) aumento del poder adquisitivo de los súb-

\footnotetext{
${ }^{103}$ Cipolla, C. M., Historia Económica de la Europa Preindustrial. Madrid 1976, págs. 187188.

104 KaMEN, H., Op. cit., pág. 214

105 AGS, CJH, leg. 1.499. Real Decreto de 3 de febrero de 1686; leg. 1.508. Reales Decre-
} 
ditos derivado, en parte, del descenso de la presión fiscal, palpable desde $\left.1683 ; 5^{\circ}\right)$ mayor independencia financiera del estado, no sujeto como antes a los dictados de los hombres de negocios, a los que se exige el 6 de enero de 1686 afianzar sus contratos con censos y no con juros, y meses después liquidar las cuentas que tienen pendientes con la Real Hacienda, amenazándoseles, si no lo hacen, de perder «las mercedes de alimentos» que reciben como subvención mientras se determina por los contadores reales el volumen exacto de sus créditos y deudas. Buena prueba de esto es que los banqueros portugueses e italianos desaparecen de las negociaciones en el bienio 1686-1687 y que a partir de esta fecha su presencia es cada vez menor, sustituidos por los españoles, aun cuando éstos tampoco adquieren la primacia de aquellos en el pasado, pues ahora se prefire recurrir a los donativos para sufragar los gastos de la administración estatal y de la politica exterior. En este sentido se puede recordar el obtenido del Consulado de Sevilla en 1686 por importe de 800.000 pesos $^{106}$.

Estemos o no en lo cierto de atribuir a los factores antedichos la decisión del conde de Oropesa de modificar la relación plata/vellón, lo evidente es que la Real Pragmática de 14 de octubre de 1686 establece que el marco de plata en pasta, que valia sesenta y cinco reales de plata, y del que se labraban sesenta y siete reales, valdrá en adelante ochenta y un reales y un cuartillo, «que es la cuarta parte más que se da de crecimiento al valor del marco de plata», acuñándose a partir de ahora ochenta y cuatro piezas o reales de plata con valor de treinta y cuatro maravedies, y en esta conformidad los reales de a ocho, de a cuatro y de a dos - se retoma una talla promulgada en 1642, que al parecer no prosperó ${ }^{107}$-. El peso de las nuevas piezas será, por lo tanto, de 21,90,

tos de 3 de febrero y 5 de marzo de 1686; Canga Arguelles, J., Diccionario de Hacienda. Madrid 1833-34, I, pág. 206. En este año de 1686 se promulga también la suspensión de pagos de todos los juros situados sobre las rentas sin admitir las exenciones habituales que venian gozando las Iglesias, los conventos y el Consejo de la Inquisición. Ver KameN, J., Op. cit., pág. 577; Martinez Mli LÁN, J., La hacienda de la Inquisición (1478-1700). Madrid 1984, pág. 89; Álvarez Vazquez, J. A., Rentas, precios y crédito en Zamora en el Antiguo Régimen. Zamora 1987, pág. 266.

${ }_{106}$ AGS, CJH, leg: 1.508. Real Decreto de 6 de enero de 1686; Sanz Ayan, C., Op. cit., págs. 267-268; Lantery, R., Op. cit., pág. 236; GiRARD, A., Le commerce française à Seville et Cadix au temps des Habsbourg. Contribution à l'étude du commerce étranger en Espagne aux xviè et xvilè siècles. Paris, 1932, pág. 287 y ss; Garzón PAREJA, M., La Hacienda..., pág. 38. Asimismo el comercio de Cádiz anticipó cien mil pesos para el gasto de la Armada. Ver RODRIGUEz VICENTE, E, “Los cargadores a Indias y su contribución a los gastos de la monarquia, 1555-1750», Anuario de Estudios Americanos, XXXIV, 1977, págs. 211-231. La referencia está tomada del Apéndice, págs. 225-226.

${ }^{107}$ Nueva Recopilación. Auto VI, tit XXI, lib. V. Real Cédula de 23 de diciembre de 1642; Collantes Perez-Arda, E. y Merino Navarro, J. P., Op. cit, pág. 75. 
$10,95,5,47$ y 2,73 gramos. Los antiguos reales de a ocho de plata que tenían un valor intrínseco de diez reales de plata correrán con esta estimación con el nombre de escudo de plata o peso fuerte -en la misma proporción los reales de a cuatro, de a dos, sencillos y medios reales-, no variando su peso, que sigue siendo de $27,46,13,73,6,87$ y 3,43 gramos. Se reconoce el cincuenta por ciento de premio para la plata respecto del vellón, de tal modo que el escudo de plata valdrá quince reales de vellón -sus múltiplos en la misma proporción- y el real de a ocho de plata nueva con valor de ocho reales de plata, que es su valor intrínseco, doce reales de vellón -las demás piezas tendrán la equivalencia correspondiente-. Por último, se ordena que las monedas de oro se acuñen con igual peso y ley que en el pasado (la ley del escudo es de veintidós quilates y se tallan sesenta y ocho piezas por marco, lo que da un peso por pieza de 3,38 gramos), pero sobretasando su valor nominal, que se sitúa para el escudo en diecinueve y medio reales de plata, para el doblón en teinta y ocho reales de plata, y así sucesivamente para la media onza y la onza de oro, con el cincuenta por ciento de premio respecto del vellón. Con la finalidad de que salga de sus escondrijos la plata y el oro, la Pragmática establece que a los particulares que lleven sus vajillas y monedas a las cecas para labrarlas se les entregarán ochenta y dos reales de plata nueva por marco, con lo que obtienen un beneficio de tres cuartillos - la Corona se abstiene de percibir el derecho de señoreaje- ${ }^{108}$. El 4 de noviembre de 1686 se introducen correcciones de escasa importancia - se sube medio cuarto a la plata vieja, pasando de 127,5 cuartos a 128 cuartos, a fin de evitar algunos embarazos que se han observado en el trueque de la moneda de plata pequeña-, y el 26 de noviembre de 1686, a consulta del Consejo de Castilla, se eleva de nuevo el valor del oro, tasándose el doblón en cuarenta reales de plata. Finalmente, el 22 de febrero de 1687, también a consulta del Consejo de Castilla, se autoriza que los doblones de oro que estuvieren faltos de peso circulen con el valor estipulado, abonando las personas que los entregaren la diferencia de peso o descontando los mercaderes dicha cantidad del valor del doblón ${ }^{109}$.

Desde 1686, pues, el cuadro de equivalencias de las monedas en circulación y su peso es el siguiente ${ }^{110}$.

\footnotetext{
108 Ibidem, Auto XXXIV, tít. XXI, lib. V. Pragmática de 14 de octubre de 1686.

${ }^{109}$ Ibidem, Autos XXXVI, XXXVIII y XXXIX, tít. XXI, lib. $V$.

${ }^{110}$ Completamos el cuadro dado por Collantes Pérez Arca y Merino Navarro y modificamos el peso de las piezas de cobre de dos maravedies porque se tallaron treinta y siete por marco y no treinta y ocho como sostienen ambos autores (Op. cit., págs. 96-97).
} 
JUAN A. SANNCHEZ BELÉN

\begin{tabular}{|c|c|c|c|c|c|c|}
\hline MONEDAS & ESCUDOS & $\begin{array}{l}\text { PLATA } \\
\text { VIEJA } \\
\text { (PESO } \\
\text { FUERTE) }\end{array}$ & $\begin{array}{l}\text { PLATA } \\
\text { NUEVA } \\
\text { (REALES) }\end{array}$ & $\begin{array}{l}\text { VELLÓN } \\
\text { (REALES) }\end{array}$ & MARAVEDIES & $\begin{array}{l}\text { PESO } \\
\text { TEORICO } \\
\text { (GRAMOS) }\end{array}$ \\
\hline 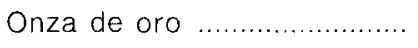 & 8 & 16 & 160 & 240 & 8.129 & 27,05 \\
\hline $\begin{array}{l}\text { Doblón de a cuatro o doble } \\
\text { doblón o media onza }\end{array}$ & 4 & 8 & 80 & 120 & 4.096 & 13,52 \\
\hline 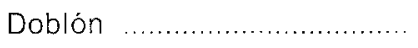 & 2 & 4 & 40 & 60 & 2.048 & 6,76 \\
\hline $\begin{array}{l}\text { Escudo } \\
\text { Real de a ocho de plata vie- } \\
\text { ja o peso fuerte o escudo } \\
\text { de plata }\end{array}$ & 1 & 2 & 20 & 30 & 1.024 & 3,38 \\
\hline $\begin{array}{l}\text { Real de a cuatro de plata } \\
\text { vieja o medio escudo de } \\
\text { plata }\end{array}$ & - & $1 / 2$ & 5 & 7 y $1 / 2$ & 256 & 13,73 \\
\hline $\begin{array}{l}\text { Real de a dos de plata vieja. } \\
\text { Real sencillo o dieciséis }\end{array}$ & - & $1 / 4$ & 2 y $1 / 2$ & 3 y $3 / 4$ & 128 & 6,87 \\
\hline $\begin{array}{l}\text { cuartos ............................... } \\
\text { Medio real de plata vieja u }\end{array}$ & - & $1 / 8$ & 1 y $1 / 4$ & 1 y $7 / 8$ & 64 & 3,43 \\
\hline $\begin{array}{l}\text { ocho cuartos ................... } \\
\text { Real de a ocho de plata }\end{array}$ & 一 & $1 / 16$ & $5 / 8$ & $15 / 16$ & 32 & 1,71 \\
\hline $\begin{array}{l}\text { nueva } \\
\text { Real de a cuatro de plata }\end{array}$ & - & 一 & 8 & 12 & 408 & 21,90 \\
\hline $\begin{array}{l}\text { nueva } \\
\text { Real de a dos de plata nue- }\end{array}$ & - & - & 4 & 6 & 204 & 10,95 \\
\hline $\begin{array}{r}\text { va o peseta ......................... } \\
\text { Real sencillo de plata nueva }\end{array}$ & - & 一 & 2 & 3 & 102 & 5,47 \\
\hline $\begin{array}{l}\text { o Real Maria .................... } \\
\text { Nueva pieza de dos mara- }\end{array}$ & - & - & 1 & $1 \times 1 / 2$ & 51 & 2,73 \\
\hline $\begin{array}{l}\text { vedies u ochavo } \\
\text { Carilla o pieza de dieciséis }\end{array}$ & 一 & - & - & - & 2 & 6,21 \\
\hline $\begin{array}{l}\text { maravedies nominales ..... } \\
\text { Cobre de ocho maravedies }\end{array}$ & - & - & - & 一 & 4 & 4,51 \\
\hline $\begin{array}{l}\text { nominales u ochavo .......... } \\
\text { Cobre de cuatro maravedies }\end{array}$ & - & - & - & - & 2 & 2,26 \\
\hline $\begin{array}{l}\text { nominales } \\
\text { Cobre de dos maravedies }\end{array}$ & - & - & - & - & 1 & 1,13 \\
\hline nominales o blanca .......... & - & - & - & - & $1 / 2$ & 0,57 \\
\hline
\end{tabular}

La subida del oro en un 6,66 por ciento modifica la relación oro/plata: si antes era de 1 a 15 ahora es de 1 a 16,48. Esto suscitará las protestas de Gran Bretaña y Francia, donde esta relación era inferior -en Hamburgo, a decir de Pierre Vilar, la equivalencia oro/plata era de 1 a 14,80 y en el Reino Unido de 1 a 15,29_-, alegando que sus comerciantes per- 
derian dinero con el cambio a la hora de cobrar sus créditos, lo cual, evidentemente, es una falacia, máxime cuando en la Prágmática de 14 de octubre de 1686 se previene que los préstamos, deudas y demás obligaciones se abonarán en plata nueva o vieja con los valores establecidos nuevamente, sin agravio de nadie ${ }^{111}$. No obstante, por si quedara alguna duda, en los meses de octubre y de noviembre, a consultas del Consejo de Castilla, se promulgan una serie de autos que regulan a su vez el pago de las obligaciones y de las letras, tanto en plata como en oro ${ }^{112}$.

\section{ÚLTIMAS VOCES ARBITRISTAS CONTRA EL. SISTEMA MONETARIO}

Con la reforma monetaria de 1680/1686 el Estado consigue frenar el proceso inflacionista que vivía el pais. Estudiando los números índices elaborados por Hamilton vemos que los precios descendieron en ambas Castillas y en Andalucia: en 1676-1680 se situaban en un 103,5, 103,6 y 105,6 respectivamente; en 1681-1685, en cambio, bajan al 65,7,60,1 y 69,3, experimentando una nueva caida entre $1686-1690$, pues pasan a $59,0,56,6$ y 56,5. Durante el decenio 1691-1700 los precios se estabilizan, pero la Guerra de Sucesión provoca un alza espectacular. Este fenómeno se observa también en el precio de los cereales, aunque no en la misma medida, puesto que los años 1681-1685 fueron de malas cosechas, al igual que el período 1696-1700. En cuanto a los salarios, los indices bajaron en una proporción menor que los precios. Tomando el caso de Castilla la Vieja, el índice de precios en 1679 ascendió a 178,9 y en 1682 a 88,6, en tanto que los salarios evolucionaron en los mismos años desde el índice 114,9 al 78,5, es decir, un dieciocho por ciento por debajo de aquellos, lo que supone una mayor capacidad adquisitiva de los salarios y mejores condiciones para incrementar el consumo, el ahorro o la inversión, garantizados, por otro lado, con una presión fiscal menor, sobre todo de los impuestos indirectos ${ }^{113}$.

La reforma monetaria emprendida es importante además porque el crecimiento del oro respecto de la plata facilitaba su entrada en el reino, si bien en la práctica no se produjese en grandes cantidades ante la es-

\footnotetext{
${ }^{111}$ Nueva Recopilación, Auto XXXIV, tít. XXI, lib. V. Pragmática de 14 de octubre de 1686 Articulo 6; Dominguez OrTiz, A., Op. cit., pág. 216, nota 32; Vilar, R., Oro y moneda en la historia, 1450-1920. Barcelona 1972, 2. ${ }^{a}$ ed, pág. 337.

112 Ibidem, Autos XXXV y XXXVII, tit. XXI, lib. V.

${ }^{113}$ HamiLton, E. J., Guerra y precios..., págs. 154, 218-224 y 250.
} 
casa capacidad comercial y fabril de Castilla para aumentar sus exportaciones y atraer con ellas el oro y la plata de Europa. Con todo, la medida fue positiva en los cambios internacionales, pues la Corona no perderá tanto dinero como antes en las provisiones realizadas a partir de ahora hacia los Países Bajos e Italia. Quizá esto nos ayude a comprender, junto a las crisis financieras de los banqueros desde mediados del siglo XVII, que las firmas italianas apenas intervengan en los asientos y que las aportaciones portuguesas decaigan de manera notable en las últimas décadas de la centuria, destacando en cambio las españolas, aun cuando el volumen de sus asientos tampoco sea el mantenido entre 1666 y 1679. Esto nos induce a pensar que el Estado habia resuelto a su modo, sin contar con los hombres de negocios, la provisión de las necesidades militares y de gobierno, menores, todo hay que decirlo, que en el pasado ${ }^{114}$.

Sin embargo de estos logros, considerados por la historiografía como decisivos para la recuperación de la crisis económica castellana, todavía encontramos algunas quejas sobre la situación monetaria resultante de 1680-1686. En un memorial del cronista Salazar y Castro, fechado en 1687. se arremete contra los partidarios de "reintegrar la misma moneda si se hallare y devaluar el precio de la plata y el valor de la moneda de cobre", pues la falta de dinero, según estos críticos, es una consecuencia directa de la reforma, y aplicándose sus arbitrios aumentaria el caudal en circulación ${ }^{115}$. Ciertamente, la baja de la moneda de molino, el descenso de los precios y el retraimiento de los inversores originaron la quiebra en muchos lugares, en particular en los de tradición artesanal, no recuperados aún en 1685, como Ajofrín, Fuensalida, Menas Alvas, Orgáz y Torrijos, en Toledo; Borcilla de la Sierra y Las Navas del Marqués, en Ávila; Cardenete y La Cierva, en Cuenca; y Ceheguin en Albacete ${ }^{116}$. Pero el vigor que se observa entre 1686 y 1691 en el desarrollo de la industria, con el establecimiento de artesanos extranjeros y la concesión de franquicias a los productos fábricados, medidas que favorecen al mismo tiem-

114 Sanz Ayan, C., Op. cit., págs. 493, 495-497.

115 Salazar y Castro, L., Discurso político sobre la flaqueza de la Monarquia española en el reinado de don Carlos Segundo y válimiento del conde de Oropesa. Año de 1687, en Semanario Erudito. Madrid 1787, vol. Il, págs. 129-144. La referencia a la moneda en la pág. 134.

116 AGS, CJH, leg. 1.480. Consultas del Consejo de Hacienda de 17 y 26 de mayo, 13 de septiembre, 7 de agosto y 23 de octubre de 1685, y del 10 de enero de 1686; leg. 1.495. Consultas del Consejo de Hacienda de 16 de mayo y 23 de julio de 1685; leg. 1.504. Consulta del Consejo de Hacienda de 24 de octubre de 1686; Contadurias Generales, leg. 753. Reales Cédulas de 25 de febrero de 1687 y 2 de julio de 1685. 
po la repoblación de ciertas localidades ${ }^{117}$, viene a confirmar el éxito de la reforma monetaria y la inexactitud de falta de numerario en el reino.

- Frente a esta corriente inmovilista - desconocemos quienes la defendian porque nada al respecto nos dice Salazar y Castro-, es preciso referirnos al memorial de Francisco de Espinosa y Velarde, escrito tras la Pragmática de 14 de octubre de 1686. En él, su autor aboga por una nueva revalorización de la plata para poder competir mejor con las potencias europeas, Francia especialmente: si los reales de a ocho antiguos y los de plata nueva que se han tasado en quince y doce reales de vellón se hubieran cotizado al doble, y en similar correspondencia los ochavos y la calderilla, los extranjeros no tendrían interés en sacar la moneda del reino, la Corona podría fácilmente desempeñar la Real Hacienda y los vasallos aumentarian su capacidad adquisitiva, pudiendo así "pagar tantos atrasados como deben, que por su suma pobreza están imposibilitados" ${ }^{118}$. Buenas intenciones le animaban, aunque su proyecto no tuviese en cuenta la realidad económica de Castilla ni los peligros que podía generar un crecimiento tan considerable del valor nominal de la plata. Para la mayoria de los arbitristas, por el contrario, desde 1686 la cuestión de la moneda desaparece de sus preocupaciones, centradas en proteger nuestro comercio e industria a través de compañias comerciales, reavivando asi una polémica antigua, en aumentar la rentabilidad de la tierra por medio de sistemas de riego, y en mejorar la organización políticoadministrativa de la Monarquía ${ }^{119}$. Ello nos induce a suponer que en las décadas finales del siglo XVII los contemporáneos tenian la certidumbre de que la crisis económica había sido superada y que el país estaba en vias de recuperarse, aunque muchas cosas todavia fueran susceptibles de mejora.

\footnotetext{
11i Fortea Pérez, J. I., «La industria textil en el contexto general de la economía cordobesa entre fines del siglo xvII y principlos del xvIII: Una reactivación fallida", Andalucia Moderna. Actas // Coloquios Historia de Andalucía. Córdoba 1983, vol. I págs. 443-446; MoLAs RiBalta, P., "Iniciativas textiles en Andalucía (1680-1700), Andalucia Moderna..., vol. 1, págs. 481-198: SANCHEZ BELEN, J. A., «La politica repobladora del reinado de Carlos II», Espacio, Tiempo y Forma, serie IV, n. ${ }^{3}$, 1990, págs. 213-233.

118 BNM, VE, 209/109

19 Álvarez Osorio y Redin, M. Compañía Universal de fábricas y comercios, BNM, VE, 8/ 9 y Zelador General para el bien común de estos reinos..., BNM, Mss. 6.659, fols. 161-180; VARINAs, Marqués de, Representación a S.M. sobre los remedios de la Monarquia, 15 de julio de 1691, BNM, Mss. 1001, fols. 236-242.
} 
CONCLUSIÓN

Entre 1665 y 1686 la literatura arbitrista, o los escritos más sobresalientes, nos sitúa ante uno de los problemas capitales de la Monarquía Hispánica en aquellos años: la inflación de los precios. Se puede discutir si su origen data de las manipulaciones monetarias de la época de Felipe III y Felipe IV o si depende de otras variables. No vamos a entrar en liza. Lo que nos importa subrayar, en cualquier caso, es que para las mentes más lúcidas de Castilla el desorden monetario es la causa de la crisis económica y financiera del reino. Los remedios apuntados por Francisco Centani, fray Juan de Jesús, Sebastián Muñoz Suárez, Antonio Somoza y Quiroga, Jorge Wallis o Juan de Arizmendi coinciden en un aspecto: se debe subir el valor facial de los reales de plata y de los escudos equiparándolos con las monedas de la misma especie que circulan en Europa; al mismo tiempo, es imprescindible modificar la relación platal cobre en beneficio de la primera.

Hasta 1679 la Corona no se decidió a abordar la reforma monetaria solicitada y cuando lo hizo el 10 de febrero de 1680 ignoró los memoriales de los arbitristas: únicamente se devaluó la moneda de molino con liga de plata y la de cobre con igual peso, tasándose las piezas de ocho maravedies - desde 1664 este era el valor de las piezas antiguas de dieciséis maravedies - en dos maravedies, y en esta proporción las restantes. Meses después, sin embargo, el gobierno decide retirar la moneda de molino, legitima o falsa, con lo que una de las reivindicaciones de los arbitristas es tomada en cuenta. Si lo que se pretendia era que la plata circulase, el objetivo no se logró. En cambio, los precios descendieron pasado el primer sobresalto gracias, sin duda, a los aranceles establecidos en todas las ciudades y a pesar de la falta de numerario, lo que favoreció el trueque de mercancias. La moneda de cobre con valor de dos maravedies que se acuñó tras la deflación del 10 de febrero no fue suficiente para satisfacer la demanda; la escasez de cobre para tallar nuevas piezas y su encarecimiento a partir de 1683 ralentizó la acuñación, que se hace más continua entre 1684 y 1685, agravando la situación. Esto provoca en los ministros cierto desasosiego. Por eso diversas voces se alzan a favor de rehabilitar la moneda de molino con liga de plata, sugerencia que es aceptada por el monarca dando lugar a la Pragmática de 9 de octubre de 1684: la moneda de molino legitima que había quedado con valor de dos maravedies se tasa en cuatro maravedies y asi sucesivamente las demás piezas. Surge entonces un doble numerario de vellón: el de la nueva acuñación de dos maravedies, con un valor intrínseco muy ajustado al facial, y el de la fábrica de molino con un poder liberatorio 
algo inferior al valor que en si tienen las piezas - recordemos que es de 7,33 maravedies la de cuatro, antes de ocho-. Es verdad que se prohibe el uso de la moneda de molino falsa, pero es muy probable que al final ésta acabase sustituyendo a la de ley. Empero, lo interesante es que el país vuelve a monetarizarse, reactivándose la agricultura, la industria y el comercio. Dos años más tarde, el conde de Oropesa, de forma sorprendente - desconocemos las razones que tuvo para hacerlo, aunque habia varios factores que pudieron tener su impronta en tal decisión-, resuelve modificar la tasa de la moneda de plata respecto del vellón en un veinticinco por ciento y subir el oro en relación con la plata, pasando la paridad de $1 / 15$ a $1 / 16,48$, algo por encima de la establecida en Gran Bretaña, Francia o Alemania. Desde este instante, los arbitristas abandonan cualquier planteamiento revisionista del sistema monetario de Castilla, salvo una que otra excepción. Sus consejos, finalmente, son asumidos en líneas generales y la evolución económica del reino viene a demostrar que no andaban desencaminados en sus análisis de los males que afectaban a la Monarquía y los remedios más convenientes para levantarla de su postración. Arbitristas y gobernantes, por fin, se encontraban en el mismo punto de partida. 